\title{
Evaluación del efecto flexotorsor en edificios altos con la utilización del método de distribución fuerzas horizontales: PPG modificado
}

\section{Evaluation of effect flexotorsor at talls buildings with the utilization of method of distribution of horizontals forces: modified PPG}

\author{
Nereyda Pupo Sintras*1, Carlos A. Recarey Morfa** \\ * Universidad de Camagüey. CUBA \\ ** Universidad Central de las Villas. CUBA
}

\begin{abstract}
Fecha de recepción: 26/ 10/ 2009 Fecha de aceptación: 20/ 01/2010

Resumen PAG. $95-120$

Se presenta de forma ilustrada la aplicación del método de distribución de fuerzas horizontales: PPG modificado. El método es aplicado a un edificio de seis niveles, cuyos rigidizadores laterales están integrados por tímpanos y pórticos distribuidos en planta de forma asimétrica. Los tímpanos son de sección rectangular y sección canal, de manera que este edificio resulta suficientemente sencillo en su concepción estructural. Esto posibilita que el análisis de la distribución de fuerzas laterales pueda llevarse a cabo utilizando los modelos y la metodología de cálculo del método mencionado. Posteriormente se establecen los resultados numéricos del comportamiento plano y espacial de los rigidizadores en términos de fuerzas y desplazamientos, evaluándose la influencia del efecto del momento flexotorsor en el tímpano de sección canal. Finalmente se comparan estos resultados con los obtenidos del análisis espacial del edificio utilizando el método de los elementos finitos sustentado por los medios de computo, estableciéndose las ventajas del método PPG modificado.
\end{abstract}

Palabras Clave: Rigidizadores, sección canal, flexotorsión, pórticos rígidos, tímpanos, carga de viento

Abstract

Presented of illustrated form the application of the method of distribution of horizontal:PPG modified. The method is applied at a building of six levels, whose lateral stabilizers are integrated for shear walls and frames distributed in plant of asymmetric form. The shear walls are from rectangular section and section canal, so that this building proves to be sufficiently simple in its structural conception. This makes possible that the analysis of the distribution of lateral forces may take effect utilizing the models and the methodology of calculation of the mentioned method. At a later time establish its numerical results of the plane and space behaviour of stabilizers in terms of forces and displacements, to evaluating the influence of the effect of the moment flexotorsor in the shear walls of section canal. Finally compare these results with the obtained ones belonging to space analysis of the building utilizing the method of the finite elements supported by the computer midways, becoming established the advantages of the method modified PPG.

Keywords: Stabilizers, channel section, flexotorsión, rigid frame, shear walls, wind load

\section{Introducción}

La búsqueda de modelos y métodos de análisis bajo la óptica de tomar en cuenta la mayor cantidad de aspectos que influyen en la distribución de fuerzas laterales en edificios, es un aspecto que está en constante investigación y desarrollo.

Diferentes trabajos de investigación sobre esta temática han sido realizados por destacados especialistas, [Lin (1964)], [Hernández (1967)], [Ruiz (1975)], [Ruiz (1979)], [Gonzáles (2004)], [Fernández (1993)], [Tejera (1992)] enfocándose la temática desde diferentes puntos de vista.

\section{Introduction}

To find models and analysis methods, considering the biggest quantity of aspects that influence lateral forces of buildings, is a matter in constant investigation and development.

Prestigious researches have done different analysis over this subject, [Lin (1964)], [Hernández (1967)], [Ruiz (1975)], [Ruiz (1979)], [Gonzáles (2004)], [Fernández (1993)], [Tejera (1992)] with emphasis on different points of view.

\footnotetext{
1 Autor de correspondencia / Corresponding author:

E-mail: nereyda.pupo@reduc.edu.cu
} 
En los mismos, se abordan temáticas sobre disposición de rigidizadores en planta, tipologías de rigidizadores, influencia del efecto del momento flexotorsor en estructuras monótonas así como la evaluación de la fuerza cortante con la altura entre otros aspectos. Los procedimientos establecidos se limitan a considerar solamente la rigidez del tímpano, sin embargo es conocido que los pórticos también aportan rigidez en su propio plano [Tejera (1992)]. Los resultados que se obtienen de este enfoque resultan muy aproximados para estructuras muy esbeltas, pues se asumen los desplazamientos como funciones continuas con la altura y no como variables discretas.

Para darle solución exacta a una serie de rigidizadores que no tenían respuesta, se adecua el método de la rigidez con enfoque matricial espacial al tema de distribución de fuerzas laterales conocido como el método PPG [Pimpo, Prendes, Gregorio (1994)], con la principal limitante que solo considera rigidez de los rigidizadores en su propio plano.

Sin embargo en la práctica de la ingeniería estructural, las secciones transversales de las estructuras resistentes verticales o rigidizadores utilizadas en estructuras de edificios altos son generalmente abiertas y con unas dimensiones tales que las tres son de diferente orden y magnitud, tales como secciones I, C, T, etc, cuando las mismas se someten a torsión, desplazamientos producto del alabeo se presentan y pueden desarrollarse altas tensiones en toda su longitud.

Este fenómeno denominado efecto flexotorsor genera un incremento significativo de rigidez que no se manifiesta en el estado de solicitación de torsión simple.

En este comportamiento las secciones transversales no se mantienen planas, alabean, por lo que no es válida la teoría de Saint Venant. La solución de este estado de solicitación en tipologías de rigidizadores de paredes delgadas se basa en la teoría de la flexión y torsión de perfiles de paredes delgadas y sección abierta desarrollada por Vlasov, (1940).

Tomando en consideración este hecho físico (alabeo seccional o efecto flexotorsor), seis grados de libertad por nudo no son suficientes, siendo por tanto una necesidad la introducción de un séptimo grado de libertad asociado al mismo, es decir además del giro considerar también el alabeo de manera independiente.

Se estima entonces la rigidez a la flexotorsión con mayor precisión y claridad al considerar el giro y el alabeo de forma independiente [Fujitani, Y; Fujii, D (1998); Ruiz, S; Bonilla, O (2006); Vallecilla, (2006)].
They touched subjects as stabilizers in the plant and its classification, influence of the flexure torsion effect in uniform structures, also the shear force assessment at height within other matters.

The process in place only considers rigidity of shear walls, nevertheless is known that frames also produce rigidity in its own plan [Tejera (1992)]. The results of this approach are closer to slim structures, because movements are considered continuous functions at height, and no discrete variables.

The exact answer for stabilizers comes from an up-dated method of rigidity, with approach on matrix space to lateral forces, known as PPG [Pimpo, Prendes, Gregorio (1994)], with the only limitation that it only considers the stabilizers rigidity in its own plan.

Howover in the practice of structural engineering, the transverse sections of the strong vertical structures or stabilizers, used in high buildings, usually are opened with three sizes that are different in order and magnitude, such as sections I, C, T, etc, when they are subjected to torsion, deformation due to movement, high tension appears and may be present in all its length.

This phenomena called flexure torsion effect, produces a global increase of rigidity, which is not shown in the state of simple torsion load.

The transversal sections do not remain flat in this behavior; they are deformed, then the Saint Venant theory is not valid. The solution for the state of this stabilizer load within thin walls is based on Vlasov theory of flexure torsion profiles for thin walls and opened sections, (1940).

Considering this physical fact (sectional deformation and flexure torsion effect), six degree of freedom per node is insufficient, there the need to have a seventh grade of freedom associated to it, that's to say besides the turn, deformation should be considered independent.

Being more accurate, the flexure torsion rigidity is better estimated considering an independent turn and deformation [Fujitani, Y; Fujii, D (1998); Ruiz, S; Bonilla, O (2006); Vallecilla, (2006)]. 
En estos trabajos se parte de la teoría de la torsión restringida para la obtención de coeficientes de rigidez en vigas de pared delgada y de sección abierta .El desarrollo considera la acción de un nuevo elemento mecánico, el bimomento, y su grado de libertad asociado dando como resultado una nueva matriz de rigidez, que tiene como desventaja el incremento del orden, al incrementarse el número de términos.

Debido a esta limitante que lleva implícita el incremento del orden de la matriz de los rigidizadores $\left(r_{i}\right)$ con estas características y por ende el incremento de la matriz general del sistema $(K)$, se valora en este trabajo la inclusión de este efecto tomando en consideración en un solo término el efecto de giro y del alabeo, estimándose la rigidez a la flexotorsión a partir de la solución general y particular de la ecuación diferencial de cuarto orden de la torsión restringida [Vlasov, V (1961), Gutiérrez, P (1964), Ruiz, S; Bonilla, O (2006); Vallecilla, (2006)].

Este importante aspecto del comportamiento en rigidizadores de paredes delgadas y sección abierta se integra a la formulación del método PPG quedando modificado para evaluar el efecto flexotorsor en rigidizadores que por sus características geométricas pueden considerarse de paredes delgadas y sección abierta [Pupo Recarey (2001)], [Recarey, Pupo (2003)], [Recarey, Pupo (2004)].

Dada las posibilidades que tiene la formulación anterior, se expone la evaluación de este efecto en una estructura de edificio de seis niveles, empleándose el método PPG modificado. Los rigidizadores laterales están integrados por pórticos y tímpanos de sección rectangular y de sección canal, los cuales tienen la misma altura. En el ejemplo, se consideran como cargas laterales las componentes estáticas del viento.

\section{Fundamentos teóricos}

Los principales aspectos de la formulación inicial del método PPG y su posterior modificación (método PPG modificado) están explícitos en los trabajos precedentes de investigación de los autores [Pupo, Recarey (2001)], [Recarey, Pupo (2003)], [Recarey, Pupo (2004)], por lo que se hará énfasis en los aspectos esenciales para su correcta implementación.

\section{Hipótesis del método}

Siempre que se desee dar solución a un problema estructural es necesario realizar una modelación de la geometría de los elementos y de la edificación en su conjunto,
The base of this paper is in the theory of limited torsion to obtain rigidity coefficients at from beams of thin walls and opened section. The development considers the action of a new mechanical element, the bimoment, and its associated level of freedom generating a new matrix of rigidity, which disadvantage is an increase in order, due that the quantity of numbers augments.

Due to this limitation - which considers the increase of stabilizer matrix order $\left(r_{i}\right)$ with that characteristics, and in consequence the increase of general system matrix $(\mathrm{K})$ - the value of this paper is to include this effect considering in one single term the effect of turn and deformation, estimating the rigidity to flexure torsion through the fourth degree differential equation of limited torsion [Vlasov, V (1961), Gutiérrez, P (1964), Ruiz, S; Bonilla, O (2006); Vallecilla, (2006)].

This important aspect of the stabilizers, with thin walls and opened section, is integrated to the formulation of PPG method, with modification to asses the flexure torsion effect in stabilizers, which by its geometrical characteristics may be considered of thin walls and opened section [Pupo Recarey (2001)], [Recarey, Pupo (2003)], [Recarey, Pupo (2004)].

According to the possibilities of the last formula, the following is the effect in a six floor building, using the modified PPG method. The lateral stabilizers are integrated through frames and shear walls of rectangular and channel section, which has the same height the example, considers as lateral loads the static components of wind.

\section{Theorical base}

The main aspects of the initial formulation of PPG method and its later modification (modified PPG method) are contained in the precedent research of the authors [Pupo, Recarey (2001)], [Recarey, Pupo (2003)], [Recarey, Pupo (2004)], thus the emphasis on the essential aspects for its correct implementation.

The Hypothesis of Method

Always before solving a structural problem, the process

is to modulate the geometry of elements and building within its set, 
del comportamiento de los materiales y de las cargas o acción de los agentes externos, para así concebir y establecer el modelo más apropiado o de más fácil aplicación práctica. Está claro que al realizarse la modelación, se está llevando de la estructura real a un modelo ideal equivalente y este proceso implica asumir ciertas hipótesis como válidas que simplifican el fenómeno físico real.

Cuando se establece un modelo es necesario asumir una serie de hipótesis simplificadoras que en este caso quedan delimitadas por:

- Se supone que el material es elástico, homogéneo e isótropo.

- Los desplazamientos son pequeños comparados con las dimensiones de la estructura de modo que puede plantearse el equilibrio en la estructura sin desplazar.

- Los pisos (entrepisos o forjados) son infinitamente rígidos en su plano, e infinitamente flexibles en la dirección normal al mismo. Se suponen conocidas las cargas actuantes de viento y/o sismo; así como otro tipo de cargas laterales.

La solución será dada sobre la base del Método de la rigidez en su enfoque matricial. Al suponerse los entrepisos infinitamente rígidos en su plano y emplearse el método de la rigidez, los desplazamientos son las incógnitas y vienen dados por tres componentes: dos lineales ortogonales y una angular (Figura 1).

Exposición general del método

En este método de análisis de estructuras de edificios es necesario identificar el sistema de rigidizadores verticales que componen el sistema estructural, que son los encargados de soportan las cargas laterales. Después de haber precisado lo anterior se define qué método de análisis se utilizará y posteriormente se asume el sistema base.

Obtención del sistema base

Para concebir el sistema base se emplea el concepto de subestructuración y se realiza un cuerpo libre independiente de cada una de las estructuras resistentes verticales (Figura 2 y 3). Además de lo anterior se realiza de forma similar un cuerpo libre de cada una de las plantas (entrepisos o forjados) que conforman el edificio (Figura 1). En los dos subsistemas bases se toma en consideración el aporte en términos de rigidez a flexión y cortante en las direcciones ortogonales y además en los casos de estructuras resistentes verticales con comportamiento espacial se toma en consideración la torsión y flexo-torsión (en el caso de secciones abiertas). considering behavior of material and loads or the action of external agents, in order to conceive the most practical, suitable or easy to implement model. Clearly when the modeling takes place, this means going from the reality to the ideal state, and this process jeans to assume certain hypothesis as valid, simplifying the real physical phenomena.

When modeling, is necessary to assume a hypothesis to simplify, which in this case are delimitated by:

- The material is supposed to be elastic, homogeneous and isotropic.

- The displacements are reduced in comparison to the structure size, and then the structure balance may be formulated without displacement.

- The floors (areas between floors) are endless rigid in its plane, and endless flexible in the normal direction to

it. The acting wind and/or seismic loads are supposed to be known; the same as other kind of lateral loads.

The solution is based on the rigidity method based on its matrix approach. To suppose rigid extremely rigid areas between floors and using the method of rigidity, the displacements are represented by unknown variables and are determined by three components: two orthogonal linear and one angular (Figure 1).

\section{General exposition of the method}

This method of analysis needs to identify the vertical stabilizer system that forms the structural system, and which supports the lateral loads. The method of analysis to be used is determined after that identification, and then the base system is assumed.

Obtaining the base system

To obtain the base system is used the concept of under structuration, considering an independent portion of each vertical resistant structure (Figure 2 y 3 ). Besides repeating the same process with an independent portion of each plan that forms the building (areas between floors) (Figure 1). The two under systems consider a contribution in terms of flexural and shear rigidity and shear in orthogonal direction, besides torsion and flexure torsion in case of vertical resistant structures with spatial behavior (in the case of opened sections). 
En el subsistema base de cada nivel (forjado o entrepiso), la modelación se hará planteando tres ligaduras en cada piso, dos ligaduras lineales ortogonales y una angular (Figura 1).

\section{Desarrollo del Método}

Se sabe que la ecuación matricial del método de los desplazamientos es
The modeling in the under subsystem at each base level (space between floors) will be with three joints at each floor, two orthogonal linear and one angular (Figure 1).

\section{Method development}

The known displacement matrix method equation is

$P=K Z \quad(1)$

donde:

P: Vector de los términos independientes.

K: Matriz rigidez de la estructura.

$Z$ : Vector de los desplazamientos lineales y angulares por pisos.

La matriz rigidez $K$ es cuadrada y su tamaño es 3n $x$ 3n, (donde $n$ es el número de pisos o niveles que tiene la edificación). La obtención de esta matriz es fundamental siempre que se aplique el Método de la rigidez con enfoque matricial. Sustituyen en la ecuación (1) la matriz rigidez (K) y el vector de los términos independientes (P) se obtienen los desplazamientos lineales y angulares en cada nivel del edificio. where:

P: Vector of independent terms.

K: Structure rigidity matrix.

Z: Vector of linear and angular displacements per floor.

The rigidity matrix $K$ is quadratic and its size is $3 n \times 3 n$, (where $n$ is quantity of floors that the building has). Always that the Method of Rigidity with matrix approach is used, reaching the matrix is fundamental. Replacing in the equation (1) rigidity matrix $(K)$ and the vector of independent terms $(P)$ results the linear and angular displacement at each level of the building.

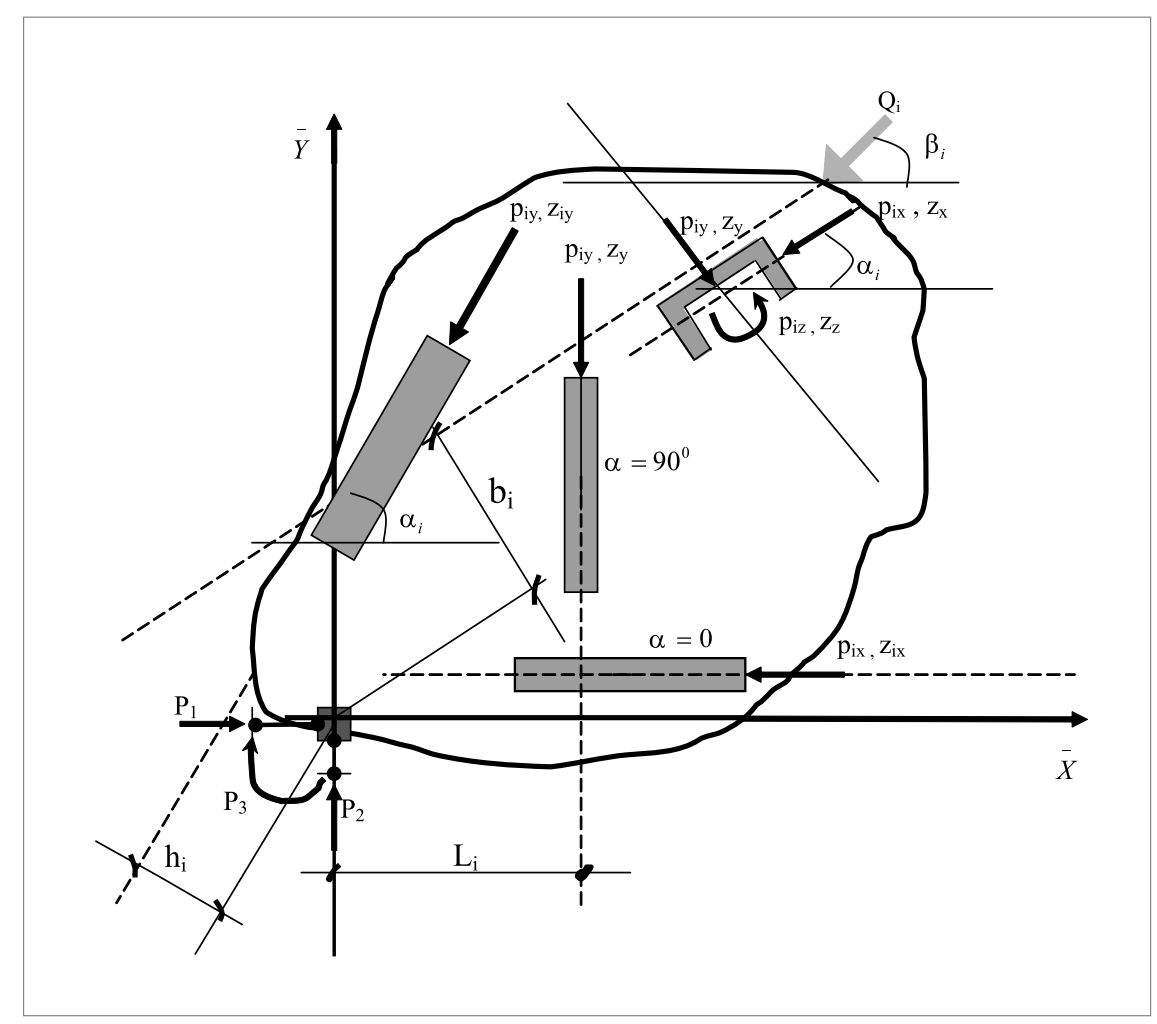

Figura 1. Sistema base de un piso cualquiera

Figure 1. Ordinary floor base system 
Para comenzar el cálculo de K, se plantea la Ecuación:
The following Equation is expressed to calculate $\mathrm{K}$ :

$$
\underline{p}=k \cdot \underline{z}
$$

donde:

$\underline{p}$ : Vector de las acciones de los rigidizadores sobre los pisos.

$z$ : Vector de los desplazamientos en las direcciones de $\underline{p}$. $k$ : matriz rigidez ordenada por piso.

El cálculo de la matriz $\mathrm{K}$ de forma indirecta es relativamente sencillo y fácil de computarizar, para ello es necesario la aplicación del Principio del Contragradiente [Pimpo, Prendes, Gregorio1994] que implica que: where:

$\underline{p}$ : Vector of the action of stabilizers on the floors.

$z$ : Vector of displacement in directions of $\underline{p}$. $k$ : rigidity matrix classified per floor.

The indirect calculus of the matrix $K$ is rather simple and easy to computerize, for that the Contragradient Principle should be applied [Pimpo, Prendes, Gregorio1994] and that means:

$$
\underline{P}=\mathrm{C}^{\mathrm{t}} \underline{p}
$$

La matriz $\mathrm{C}$ se denomina matriz conexión y $\mathrm{C}^{\mathrm{t}}$ matriz conexión transpuesta.

Cálculo de la matriz rigidez de la edificación aplicando el método indirecto

Haciendo abstracción de las cargas $Q$ (ya que se está calculando una rigidez y la misma es independiente de las cargas externas), se tiene para el caso general (Figura 1):
The Matrix $\mathrm{C}$ is called connection matrix and $\mathrm{y}$ $C^{t}$ transposed connection matrix.

Calculating the building rigidity matrix using the indirect method

Abstracting $Q$ loads (due that rigidity is independent to the external loads), in global basis is given the following (Figure 1):

$$
\left\{\begin{array}{l}
P_{1} \\
P_{2} \\
P_{3}
\end{array}\right\}=\left[\begin{array}{ccc}
\cos \alpha & \operatorname{sen} \alpha & 0 \\
\operatorname{sen} \alpha & \cos \alpha & 0 \\
h & L & 1
\end{array}\right] \cdot\left\{\begin{array}{l}
p_{i x} \\
p_{i y} \\
p_{i z}
\end{array}\right\}
$$

Para los restantes casos de una estructura resistente vertical plana las expresiones aparecen en la referencia [Recarey, Pupo (2003)]

Como el cálculo de la rigidez es independiente de las cargas externas, se obtiene del equilibrio por pisos, las matrices conexión traspuesta $\left(C_{i}^{t}\right)$ que puede expresarse matricialmente como se indica en la Ecuación 3:
The rest of the cases of a flat vertical resistant structures are explained in reference [Recarey, Pupo (2003)]

As the rigidity calculus is independent to external loads, equilibrium per floor, transposed connection matrix $\left(C_{i}^{t}\right)$ are obtained, which can be expressed in the matrix as indicated in Equation 3:

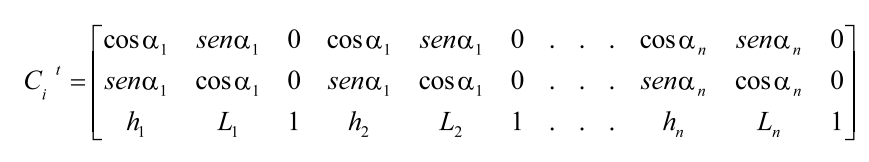

Analogous expressions (3) can be formulated for the rest of floors. As all of these expressions are independent among them, that is to say as the equilibrium is given by each level, then the transposed connection of the matrix is expressed as followed: 


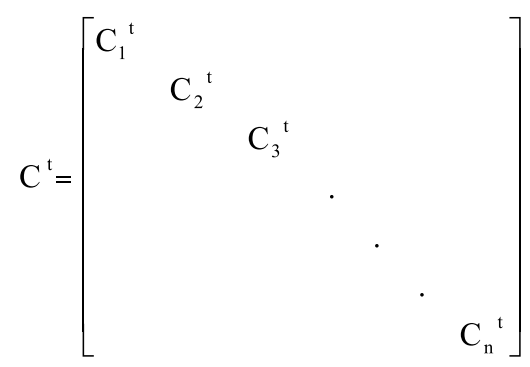

donde:

$\mathrm{C}_{1}, \mathrm{C}_{2} \mathrm{t}_{2} \ldots . ., \mathrm{C}_{\mathrm{n}}^{\mathrm{t}}$ : Matriz conexiones traspuestas del nivel $1,2, \ldots ., n$.

n: número de niveles de entrepiso.

Por el principio del contragradiente se deduce where:

$\mathrm{C}_{1}, \mathrm{C}_{2}{ }_{2} \ldots . ., \mathrm{C}_{\mathrm{n}}$ : Matrix of transposed connections at level $1,2, \ldots ., n$.

n: the number of levels between floors.

Deduction from the contragradient principle: que:

Ahora, para calcular K por la expresión (5) solo falta obtener $k$ por el método indirecto al que antes se hizo referencia. Para ello, se parte de la expresión (6) la cual se puede aplicar considerando la hipótesis de respuesta elástica de los materiales que conforman la edificación. Esta hipótesis es válida si se tiene en cuenta la naturaleza de las cargas (cargas de corta duración) las cuales producen acciones de carácter instantáneo sobre la estructura.
Now, through expression (5) it's possible to obtain $\mathrm{k}$ using the indirect method mentioned before. The starting point for this is expression (6) which can be used considering the hypothesis of elastic answer of the building materials. This hypothesis is valid if load nature is considered (short term loads), which produce instantaneous actions over the structure.

donde las fuerzas $q$ son las mismas fuerzas $p$, pero ordenadas por elementos verticales (rigidizadores) y no por pisos o niveles. De la misma forma los desplazamientos y son los mismos desplazamientos $z$, pero ordenados igual que las fuerzas $q$.

Entonces $r$ es una matriz rigidez ordenada por elementos verticales. Esta matriz se calcula por submatrices y queda expresada por: where $q$ and $p$ forces are the same, but arranged

$\underline{q}=r \cdot \underline{y} \quad(6)$

tical elements (stabilizers) and not by floors or levels. The displacements $y$, are the same displacement $z$, but arranged in the same way that $q$ forces.

Then $\mathbf{r}$ is rigidity matrix arranged by vertical elements. This matrix is calculated by under matrices and is expressed by:

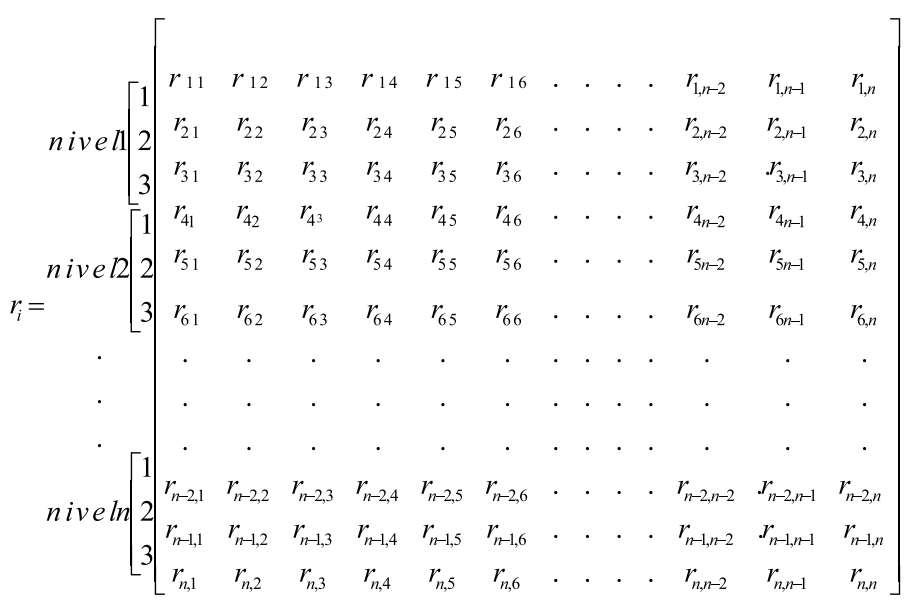


donde:

$r_{i}$ : matriz rigidez del rigidizador $i$.

$r_{i, j}$ : términos de la matriz rigidez que toman en cuenta los aportes a flexión, cortante, torsión y bimomento o efecto de flexo torsión.

En este proceso se considera tanto los rigidizadores planos, que pueden ser pórticos o marcos rígidos o pórticos mixtos con tímpanos de sección rectangular, como los rigidizadores espaciales que aporta rigidez en direcciones ortogonales a la torsión y a la flexotorsión (diafragmas o tímpanos de sección canal, I, etc.) cuya rigidez a la flexotorsión es significativa [Gutiérrez, 1964].

Conceptualmente se expresa que la rigidez es la acción generada por un desplazamiento unitario, esta acción puede ser una fuerza o un momento; para el cálculo de la misma en los rigidizadores, debemos establecer los tradicionales sistemas bases del método de rigidez introduciendo las ligaduras lineales y angulares, según corresponda.

A continuación se presentan dos tipos de sistemas base por rigidizadores: sistema base de un rigidizador plano y el sistema base de un rigidizador espacial, como se indican en las Figuras 2 y 3 respectivamente. where:

$r_{i}$ : rigidity matrix of stabilizer $i$.

$r_{i, j}$ : Terms of the rigidity matrix that considers contributions to flexure, shear, torsion, bimoment or flexure torsion.

This process considers flat stabilizers - which can be frames, rigid frames, or shear walls with rectangular section - as spatial stabilizers that contributes rigidity in orientations orthogonal to torsion and flexure torsion (diagrams and shear walls with channeled sections, I and others), which rigidity to flexure torsion is significative. [Gutiérrez, 1964].

The expression of rigidity define it as the action produced by a single displacement, this action may be a force or a moment; the calculus of rigidity on stabilizers, should set the traditional base system of rigidity of linear and angular joints, as it corresponds.

The following, two base systems for stabilizers: base system for a flat stabilizer and base system for spatial stabilizer, as Figures 2 and 3 show.

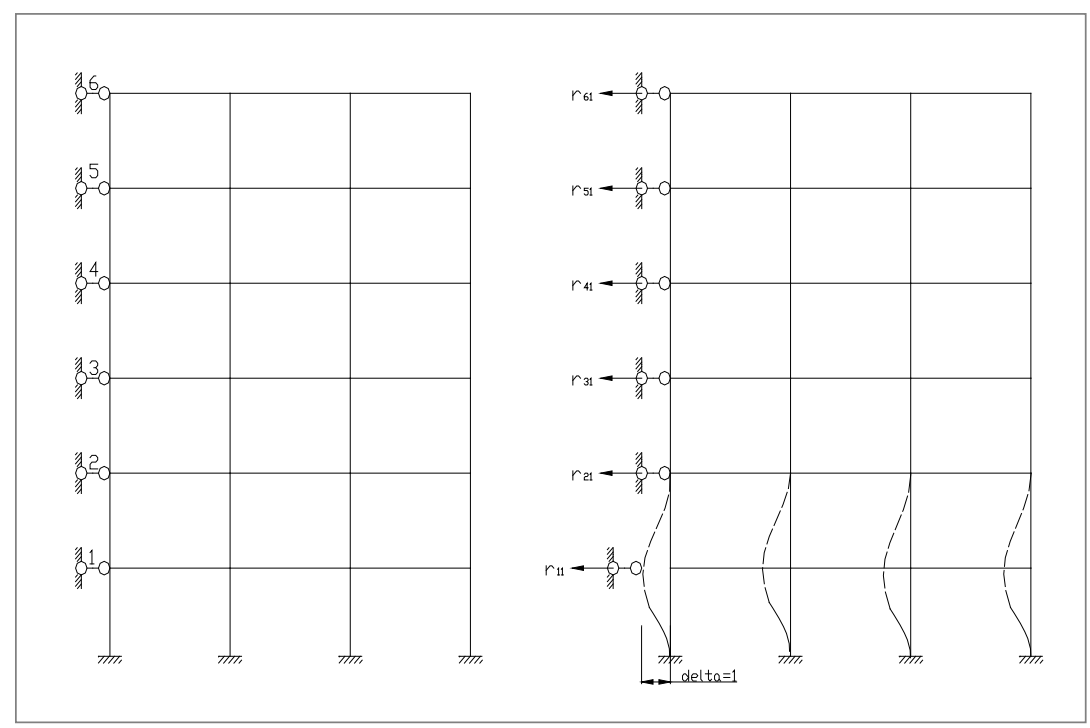

Figura 2. Sistema base de un rigidizador plano

Figure 2. Flat base system for a stabilizer 


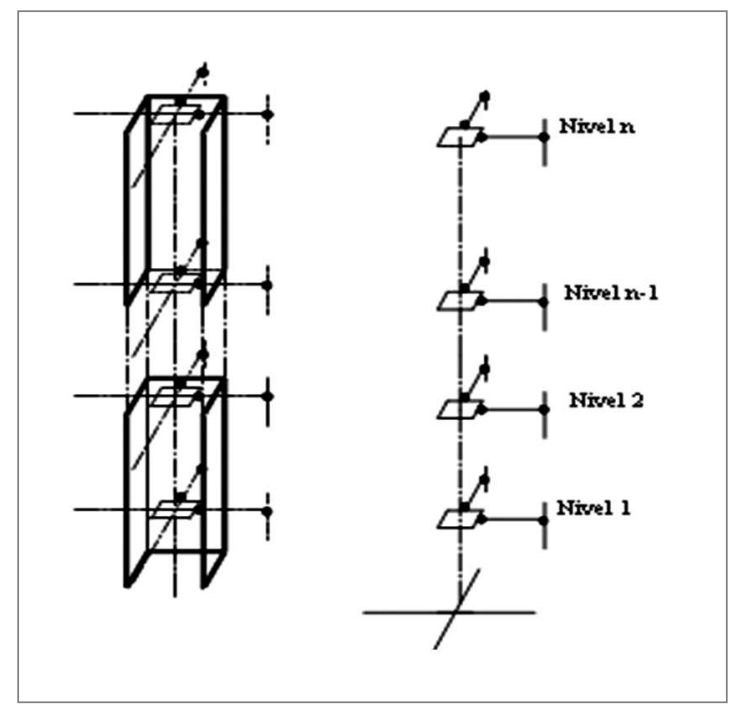

Figura 3. Sistema base de un rigidizador espacial

Figure 3. Base system of a spatial stabilizer

Determinación de la matriz de incidencia (A) y su traspuesta $\left(A_{t}\right)$

Esta es una matriz que está compuesta por 1 y 0 y es necesaria en la obtención de la matriz $k$ en función de $r$, para conformar esta matriz se ordenan los vectores desplazamientos por rigidizadores $(y)$ y por pisos (z) , la relación entre estos vectores, se establece precisamente a través de esta matriz, es decir $y=A z$, de manera que:

$$
A_{i j}=1 \text { si } y_{i}=z_{i} \quad \text { y } A_{i j}=0 \text { en caso contrario }
$$

Obtención de la matriz ordenada por pisos (k) Esta matriz se obtiene a través de la matriz $r$, la matriz A y At planteándose la expresión matricial:
Determining the incidence matrix $(A)$ and its transpose $\left(A_{t}\right)$

This is a matrix formed by $\mathbf{1}$ y $\mathbf{0}$, and it is relevant for obtaining matrix $k$ in function of $r$; to conform this matrix the displacement vectors are arranged by stabilizer (y) and for floor $(z)$, the relation between these vectors is precisely defined by this matrix, that's to say $y=A z$, then :

$$
A_{i j}=1 \text { si } y_{i}=z_{i} \text { y } A_{i j}=0 \text { in opposite case }
$$

Obtaining the matrix arranged by floors (k) This matrix is obtained through matrices, $\mathrm{A}$ and At with the following matricial expression:
Determinación de la matriz rigidez ordenada por elementos verticales $(r)$ de la estructura

Esta matriz se determina a partir de la rigidez $\mathbf{r}_{\mathbf{i}}$ de cada uno de los rigidizadores que componen la estructura como se expresó en el paso inicial del método. En los rigidizadores que aportan rigidez en una dirección, el orden de la matriz $r_{i}$ es de orden nxn y en los rigidizadores que aportan rigidez en direcciones ortogonales y al giro el orden de la matriz $r_{i}$ es de 3nx3n.

En los rigidizadores de sección abierta que tienen aporte espacial se introduce además el efecto del momento flexo-torsor modificándose la matriz $\mathbf{r}_{\mathbf{i}}$ de cada uno de estos rigidizadores, esto es, los términos múltiplos de tres que representan la rigidez al giro se sustituyen por términos de rigidez a la flexotorsión según lo expresado en la formulación modificada del método (Pupo,
Determining the rigidity matrix arranged by vertical elements $(r)$ of the structure

This matrix is determined through rigidity $r_{i}$ of each stabilizer that form the structure, as expressed in the initial step to the method. In stabilizer that contributes one orientation of rigidity, the matrix nxn order and in those that contribute rigidity in orthogonal directions and to the matrix order turn $r_{i}$ is $3 n x 3 n$.

The opened section stabilizers that contribute spatially besides have the flexure torsion moment effect, modifying the matrix $r_{i}$ of each stabilizer, in the multiple terms of three that represent rigidity to turn, they are replaced by rigidity terms to flexure torsion, according to what is expressed in the modified method (Pupo, 
Recarey (2001)) cuya rigidez se estima a partir de la interpretación del modelo matemático planteado por Vlasov (1961).

Para considerar este efecto se parte de la ecuación diferencial de segundo orden de la torsión restringida
Recarey (2001)), which rigidity is estimated through the model mathematical interpretation suggested by (1961).

The starting point for this effect is the second degree differential equation at second order over the limited torsion

$$
G I_{t} \theta-E I_{\omega} \frac{d^{2} \theta}{d z^{2}}=M_{\text {total }}(z)
$$

Introduciendo la notación $\frac{G I_{t}}{E I_{\omega}}=\alpha_{1}^{2}$

Introducing the notation $\frac{G I_{t}}{E I_{\omega}}=\alpha_{1}{ }^{2}$

Se obtiene:

$$
\frac{d^{2} \theta}{d z^{2}}-\alpha_{1}^{2} \theta=\frac{-M_{\text {total }}(z)}{E I \omega}
$$

La solución de esta ecuación queda delimitada por:

The solution of this equation is limited by:

$$
\theta=\frac{M_{\text {total }}}{G I t}\left[1+\tan g h\left(\alpha_{1} H\right) \operatorname{senh}\left(\alpha_{1} Z_{i}\right)-\cosh \left(\alpha_{1} Z_{i}\right)\right]=r_{3 i 3 j} M_{t}
$$

El desplazamiento angular máximo será:

The maximum angular displacement will be:

$$
\varphi=\int_{0}^{1} \theta d z=\frac{M l}{G I_{t}}\left[1-\frac{1}{\alpha_{1} l} t h \alpha_{1} l\right]
$$

lo que implica que:

which means:

$$
r_{3 i 3 j}=\left(r_{3 i 3 j t}+r_{3 i 3 j f t}\right)=\frac{G I_{t}}{l\left[1-\frac{1}{\alpha_{1} l} t h \alpha_{1} l\right]}
$$

donde:

$\alpha$ : Parámetro torsional característico

$\mathbf{r}_{3 \mathrm{i} 3 \mathrm{j}}$ : rigidez total considerando torsión y flexo-torsión

$\mathbf{r}_{3 \mathrm{i} 3 \mathrm{j} \text { : }}$ : rigidez a torsión

$\mathbf{r}_{3 \mathrm{i} 3 \mathrm{jft}}$ : rigidez a flexotorsión

G: módulo de cortante.

$I_{t}$ : momento de inercia a torsión.

$I_{\omega}$ : momento de inercia sectorial.

E: módulo de elasticidad o de Young

$l$ : Distancia entre un piso y el siguiente según se muestra en el esquema genérico de un rigidizador espacial de la Figura 4.

Como se plantea, en un mismo término de rigidez se tiene en cuenta el efecto conjunto de torsión y flexotorsión y este es el procedimiento que se asume en este trabajo, where :

$\alpha$ : Characteristic torsional parameter

$r_{3 i 3 j}$ : Total rigidity considering torsion and flexure torsion $\mathbf{r}_{3 \mathrm{i} 3 \mathrm{jt}}$ : Torsion rigidity

$\mathbf{r}_{3 \mathrm{i} 3 \mathrm{jft}}$ : Flexure torsion rigidity

G:Shear modulus.

$\mathrm{I}_{\mathrm{t}}$ :Torsion moment of inertia.

$\mathbf{I}_{\omega}$ :Sectorial moment of inertia.

E: Elaticity or Young modulus.

$l$ : Distance between one floor and the following according to the generic pattern for a spatial stabilizer, Figure 4

As state, in just one rigidity term can be obtained the effect of torsion and flexure torsion and this is the process of this paper, 
de forma tal que se calculan el resto de los términos de rigidez al giro realizándose el acople necesario en función de los pisos en que incida el rigidizador.

Aunque se ha asumido el procedimiento anteriormente planteado, esto no quiere decir que sea la única vía para modelar este fenómeno, de hecho existen otros procedimientos que aparecen en publicaciones relativamente recientes para estimar la rigidez a la flexotorsión, como se expresó en la parte inicial del trabajo, donde los términos de rigidez al giro y al alabeo se calculan de forma independiente, [Fujitani, Y; Fujii, D (1998); Ruiz, S; Bonilla, O (2006); Vallecilla, (2006)]. Se presenta la matriz simplificada en el caso de una estructura resistente vertical con carga lateral en correspondencia con los modelos asumidos por Ruiz, S; Bonilla, O (2006) y Vallecilla, (2006). in such way that the calculation of rigidity to turn may produce the required couple in function of the floors the stabilizer influence.

Even when the described procedure is assumed, this does not mean that is the only way to model this phenomena, in fact there are two other process that appear in recent publications and that are related to flexure torsion rigidity, as expressed in the initial paper, where terms as rigidity to turn and deformation al calculated in an independent way, [Fujitani, Y; Fujii, D (1998); Ruiz, S; Bonilla, O (2006); Vallecilla, (2006)].

A simplified matrix is presented in the case of a vertical resistant structure with lateral load in accordance with the models assumed by Ruiz, S; Bonilla, O (2006) y Vallecilla, (2006).

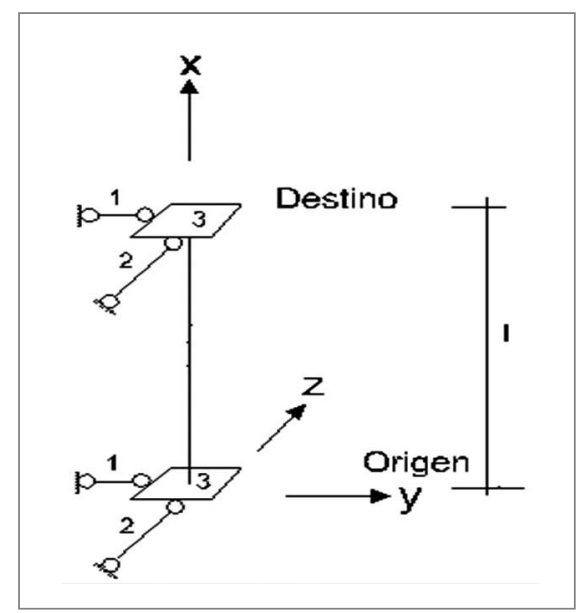

Figura 4. Esquema genérico de un rigidizador espacial Figure 4. Generic pattern of a spatial stabilizer

$$
r_{i}=\left[\begin{array}{cccccccc}
\frac{12 E I_{z}}{l^{3}} & \multicolumn{1}{c}{\text { SIMETRICA }} & & \\
0 & \frac{12 E I_{y}}{l^{3}} & \multicolumn{7}{c}{{ }^{3}} & & & & \\
0 & 0 & S_{11} & & & & & \\
0 & 0 & S_{12} & S_{22} & & & & \\
0 & 0 & 0 & 0 & \frac{12 E I_{z}}{l^{3}} & & & \\
0 & 0 & 0 & 0 & 0 & \frac{12 E I_{y}}{l^{3}} & \\
0 & 0 & -S_{11} & -S_{12} & 0 & 0 & S_{11} \\
0 & 0 & S_{12} & S_{24} & 0 & 0 & S_{12} & S_{22}
\end{array}\right]
$$


En este caso los términos que toman en cuenta el efecto flexotorsor son los términos de rigidez al giro y al alabeo, es decir, $S_{11}, S_{12}, S_{22}$ y $S_{24}$.
In this case the terms that consider the flexure torsion effect are the same of rigidity to turn and deformation, that is to say, $S_{11}, S_{12}, S_{22}$ y $S_{24}$.

$$
S_{11}=\alpha_{2} \frac{k_{1}}{l} \sinh k_{1}
$$

donde:

$$
\begin{gathered}
\alpha_{2}=\frac{G I_{t}}{\left(2+k_{1} \sinh k_{1}-2 \cosh k_{1}\right)} \\
\mathrm{S}_{12}=\alpha_{2}\left(1-\cosh \mathrm{k}_{1}\right) \\
k_{1}=l \sqrt{\frac{G I_{t}}{E I_{w}}} \\
S_{22}=\alpha_{2} \frac{l}{k_{1}}\left(k_{1} \cosh k_{1}-\sinh k_{1}\right) \\
S_{24}=\alpha_{2} \frac{l}{k_{1}}\left(\sinh k_{1}-k_{1}\right)
\end{gathered}
$$

También se presenta la matriz simplificada en el caso de una estructura resistente vertical con carga lateral en correspondencia con el modelo para el cual se considera el giro y el alabeo de forma fragmentada, es decir, se separa el efecto flexotorsor del efecto de torsión (Fujitani, Y; Fujii, D (1998));
It is also introduced a simplified matrix in the case of a vertical resistant structure, with lateral load, in accordance to the model consideirng turn and a fragmented deformation, that is to say separated from the the flexure torsion efect of torsion effect (Fujitani, Y; Fujii, D (1998));

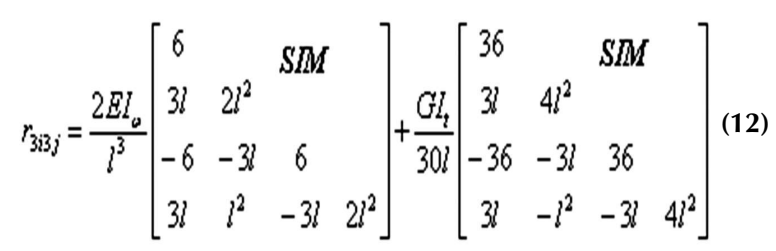

donde:

$\mathbf{r}_{3 \mathrm{i} 3 \mathrm{j} \text { : }}$ matriz rigidez simplificada de términos de rigidez al giro

En esta forma de modelar el efecto flexotorsor las funciones hiperbólicas asumidas en los modelos de los autores Ruiz, S; Bonilla, O (2006) y Vallecilla, (2006) se sustituyen por funciones parabólicas lo que genera mayor sencillez en el análisis, solo se han representado los términos de rigidez al giro y al alabeo. Este modelo de rigidez resulta equivalente al anterior, se constata que: where:

$r_{3 i 3 j}$ : simplified matrix for turn rigidity terms

In this way of modeling the flexure torsion effect, the hyperbolic functions assumed by Ruiz, S; Bonilla, $\mathrm{O}$ (2006) y Vallecilla, (2006) were replaced by parabolic functions simplifying the analysis, just representing the terms of turn rigidity and deformation. This model is equivalent to the former one and its proved:

$$
\begin{gathered}
S_{11}=\frac{2 E I_{\omega}}{l^{3}}(6)+\frac{G I_{t}}{30 l}(36) \\
\text { if } S_{11}=\alpha_{2} \frac{k_{1}}{l} \sinh k_{1} \text { then: } \\
\alpha_{2} \frac{k_{1}}{l} \sinh k_{1}=\frac{2 E I_{\omega}}{l^{3}}(6)+\frac{G I_{t}}{30 l}(36)
\end{gathered}
$$$$
\text { si } S_{11}=\alpha_{2} \frac{k_{1}}{l} \sinh k_{1} \text { entonces: }
$$ 
Y así se establece una equivalencia entre los términos múltiplos de tres de la expresión (11) con la expresión (12), el resto de los términos correspondientes a la rigidez a flexión, son similares a los de la expresión (11).

Se observa que cualesquiera de los procedimientos mencionados pueden ser empleados para el cálculo de los términos de rigidez a la flexotorsión y luego ser introducidos los mismos en la matriz general ri del elemento resistente [Pupo, Recarey, Brizuela (2004)]. Sin embargo en este trabajo se estima la rigidez a partir de la ecuación 10, por las ventajas que este planteamiento representa como ya se explicó inicialmente.

\section{Ejemplo de cálculo}

Se toma para el análisis una estructura de edificio de seis niveles tipo pantalla conformada por rigidizadores mixtos pórtico-tímpano rectangular en los extremos, rigidizadores tipo pórticos en posiciones intermedias y la ubicación del rigidizador canal según se muestra en la Figura 5.

Características de la estructura de edificio: Planta estructural tipo pantalla conformada por rigidizadores tipo tímpano rectangular ubicados en los extremos y pórtico tímpano de sección canal situado en posición intermedia, como se indica en la Figura1, la misma está conformada en su totalidad por los siguientes rigidizadores:

- Tres rigidizadores longitudinales que son sólo pórticos y se identifican por los números 9,10 y 12 en la Figura 6.

- Un rigidizador longitudinal que es en parte tímpano canal y en parte pórtico, se identifica por el número 11 en la Figura 6.

- Cuatro rigidizadores transversales que son solo pórticos y se identifican por los números 2, 3,4, 5, 6 y 7 en la Figura 6.

- Dos rigidizadores transversales que son tímpanos rectangulares 1,8 en la Figura 2, están en posiciones extremas en la estructura del edificio.
Thus an equivalent between the multiple terms of three is set, expressions (11) and (12), the rest of the terms belong to the flexure rigidity, and are similar to expression (11).

Any or the process observed can be used to calculate the flexure torsion rigidity and then introduced in the general matrix ri of the resistant model [Pupo, Recarey, Brizuela (2004)]. Nevertheless this paper estimates rigidity from the equation 10 , due to the advantages that that postulate represents, as mentioned initially.

\section{Calculus example}

A building with a structure of six levels is considered for this analysis, with a mix of stabilizers of shear wall and frames, rectangular in the edges, frame stabilizers at intermedium positions placed according to the sample in Figure 5.

Characteristics of the building structure:

Structural plan like screen, formed by rectangular wall shear stabilizers placed at the edges and wall shear frame with channel section placed at intermedium position, as indicated in figure 01 , which is formed totally by the following stabilizers.

- Three longitudinal stabilizers that are only frames and are identified by numbers 9,10 y12 in Figure 6.

- A longitudinal stabilizer that is in part wall shear channel and in part frame, identified by number 11 at Figure 6

- Four transversal stabilizers that are frames and classified by numbers at figures 2, 3,4, 5, 6 and 7 in Figure 6 .

- Two transversal stabilizers that are rectangular shear walls 1,8 in Figure 2, and are in extreme positions within the building structure.

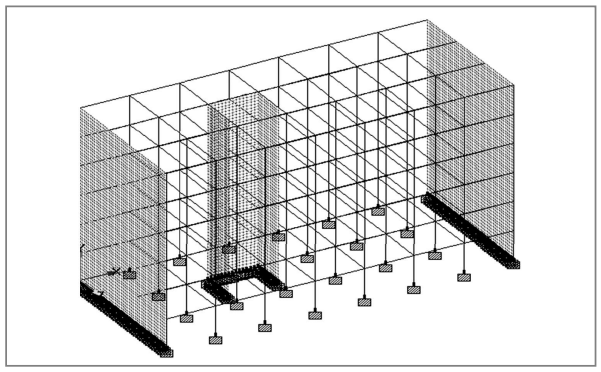

Figura 5. Estructura de edificio conformada por diferentes tipos de rigidizadores Figure 5. Building structure formed by different kind or stabilizers 


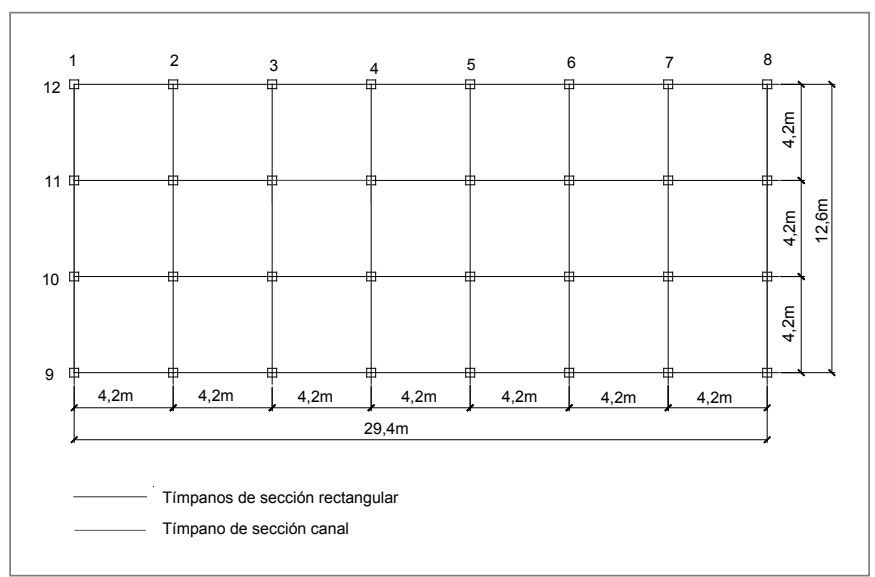

Figura 6. Planta de la estructura de edificio conformada por diferentes tipos de rigidizadores Figure 6. Plan of the building formed by different kind or stabilizers

En la Tabla 1, se representan los valores de la carga lateral de viento como fuerza horizontal externa considerada en los cálculos según la normativa vigente [NC 285-2003] y en la Tabla 2 se indican las dimensiones y propiedades de los diferentes rigidizadores presentes en el sistema estructural.
The Table 1, represents the wind lateral load as external horizontal force, considered in calculations according to the current normative [NC 285-2003] and Table 2 shows the size and properties of the different stabilizers within the structural system.

Tabla 1. Fuerza del viento concentrada en cada nivel Table 1. Wind force concentrated at each level

\begin{tabular}{||c|c|c|}
\hline Nivel & Fuerza $(\mathrm{kN})$ & Momento $(\mathrm{kN}-\mathrm{m})$ \\
\hline 1 & -80.17 & 1178.50 \\
2 & -92.2 & 1355.34 \\
3 & -104.5 & 1536.89 \\
4 & -107. & 1573.19 \\
5 & -115.3 & 1694.18 \\
6 & -61.74 & 907.58 \\
\hline
\end{tabular}

Tabla 2. Datos de la geometría y propiedades de los materiales de los rigidizadores Table 2. Geometry or stabilizer material properties data

\begin{tabular}{|l|l|l|l|l|l|l||}
\hline $\mathrm{Ac}$ & $\mathrm{Av}$ & $\delta \mathrm{r}$ & $\delta \mathrm{c}$ & $\mathrm{Eh}$ & $\mu$ & $\mathrm{G}$ \\
\hline 0.09 & 0.12 & 0.3 & 0.25 & 21969363 & 0.17 & 9388616.67 \\
\hline
\end{tabular}

$A_{c}$ : Sección transversal de las columnas $(0.3 \mathrm{~m} \times 0.3 \mathrm{~m})$ $A_{v}$ : Sección transversal de las vigas $(0.3 \mathrm{~m} \times 0.4 \mathrm{~m})$ dr: Espesor del tímpano o diafragma de sección rectangular en $\mathbf{m}$

$\delta_{c}$ : Espesor del tímpano de sección canal en $\mathbf{m}$ $E_{h}$ : Módulo de Elasticidad del hormigón en kPa. G: Módulo de Cortante en kPa

$G=\frac{E}{2(1+\mu)}$

$\mu$ : Coeficiente de Poisson
$A_{c}$ : Transversal sections of columns $(0.3 \mathrm{~m} \times 0.3 \mathrm{~m})$ $A_{v}$ : Transversal sections of beams $(0.3 \mathrm{~m} \times 0.4 \mathrm{~m})$ dr: UIT of shear wall or diagram rectangular section in m.

$\delta_{\mathbf{c}}$ : Shear wall channel section in $\mathbf{m}$.

$E_{h}$ : Modulus of concrete elasticity in $\mathrm{kPa}$.

$\mathrm{G}$ : Shear modulus en $\mathrm{kPa}$

$G=\frac{E}{2(1+\mu)}$

$\mu$ : Coefficient of Poisson 
Procedimiento:

Se precisarán los análisis realizados para establecer la comparación entre los procedimientos empleados, es decir los modelos que se emplean según el método PPG modificado y la modelización de la estructura en su conjunto a través del método del elemento finito asistido por computadora, son tres análisis (A, B y C) que se describen a continuación:

Análisis A. Modelación espacial de la estructura mediante el método PPG modificado. Todos los rigidizadores son planos.

Se establece la modelización espacial de la estructura según el método PPG modificado considerándose que los rigidizadores son planos, es decir sólo aportan rigidez lateral a la flexión y cortante en su plano, no se considera la torsión, estas rigideces son calculadas por programas de computación, posteriormente se realizan las operaciones matriciales para finalmente obtener los desplazamientos en cada nivel y los desplazamientos y fuerzas en cada rigidizador del sistema estructural analizado.

Análisis B. Modelación espacial de la estructura mediante el método PPG modificado. Se analiza el rigidizador espacial canal de sección abierta.

Se establece la modelización espacial de la estructura según el método PPG modificado como en el caso anterior, pero se incorpora el rigidizador canal de sección abierta con comportamiento espacial, en el cual se tiene en cuenta la rigidez en direcciones ortogonales, a la torsión y a la flexotorsión, estas rigideces también son calculadas mediante programas de computación y como en el caso anterior se realizan las operaciones matriciales para la obtención de los desplazamientos por niveles, las fuerzas y los desplazamientos por rigidizadores presentes en el sistema estructural estudiado, en este caso la matriz rigidez del rigidizador espacial se modifica incluyéndose los términos de rigidez a la flexotorsión, según Ecuación 8.

Análisis C. Modelación espacial mediante el método de los elementos finitos asistido por medios de computo.

Se establece la modelización espacial de la estructura mediante el método de los elementos finitos. Se utiliza un programa de computación especializado (STAAD.pro2006). Para el proceso de modelación de la geometría se seleccionan elementos rectangulares tipo shells de $30 \times 30 \mathrm{~cm}$, adecuados para la configuración regular de la estructura analizada. Se asume que todos los rigidizadores son espaciales.
Procedure:

Determination of the analysis to compare the process, that is to say the models used according to method PPG, modified and modeling the structure in its set through the finite element method, supported by computer; there are three analysis (A, B y C) described as followed:

Analysis A. Spatial structure modeling through the modified PPG method. All the stabilizers are flat.

The structure spatial modeling is set according to the PPG modified method, considering that stabilizers are flat, that is to say that they only contribute lateral rigidity to flexure and shear wall in its plan, torsion is not considered, these rigidities are calculated by computer programs, determining later matrices for obtaining each level displacements and the forces in each structural system analyzed.

Analysis B. Spatial modeling of the structure through a modified PPG method. Analyzing the spatial stabilizer channel of each opened section.

The spatial modeling structure is set according to the modified PPG, as in the previous case, but adding the stabilizer of opened channel with spatial behavior; considering orthogonal rigidity to torsion and flexure torsion, these rigidity is also calculated through computer programs, and as the previous case the matrix operations give as result the stabilizer displacements per level, the forces and displacements by stabilizers within the structure studied, in this case the spatial rigidity matrix is modified adding the terms of rigidity to flexure torsion, according to Equation 8.

Analysis C. Spatial modeling through the finite element method, with computerized support.

The computing program in used is specialized (STAAD.pro2006). The choice for modeling geometry was rectangular elements, like shells of $30 \times 30 \mathrm{~cm}$, suitable for the regular configuration of the analyzed structure. It is assumed that all the stabilizers are spatial. 
Procedimiento empleado en correspondencia con los análisis indicados.

Análisis A:

Se determinan las siguientes matrices para el cálculo:

a) Matriz rigidez de cada rigidizador $\left(r_{i}\right)$

b) Matriz rigidez diagonal por rigidizadores verticales $(r)$.

c) Matriz de incidencia (A) y su traspuesta $\left(A_{t}\right)$.

d) Matriz rigidez de rigidizadores $(k)$.

e) Matriz conexión traspuesta $\left(C^{t}\right)$ y $(C)$.

f) Matriz rigidez del sistema estructural (K)

g) Matriz rigidez de cada rigidizador $\left(r_{\mathbf{i}}\right)$

Matriz rigidez de los rigidizadores tipo tímpanos 1 y 8 de orden $6 \times 6$.

$$
r_{1-8}=\left(\begin{array}{rrrrrr}
2.84 E+07 & -1.20 E+07 & -3613.1 & -2.86 E+06 & 2.37 E+06 & 1.91 E+05 \\
-1.20 E+07 & 2.30 E+07 & -1.27 E+07 & -62244 & 3.16 E+06 & -1.54 E+06 \\
-3613.1 & -1.27 E+07 & 2.33 E+07 & -9.31 E+06 & -4.73 E+06 & 2.91 E+06 \\
-2.86 E+06 & -62244 & -9.31 E+06 & 2.17 E+07 & -1.31 E+07 & 1.66 E+06 \\
2.37 E+06 & 3.16 E+06 & -4.73 E+06 & -1.31 E+07 & 2.81 E+07 & -1.35 E+07 \\
1.91 E+05 & -1.54 E+06 & 2.91 E+06 & 1.66 E+06 & -1.35 E+07 & 9.42 E+06
\end{array}\right)
$$

Matriz rigidez de los rigidizadores 2, 3, 4, 5,6 y 7 de orden $6 \times 6$.

$$
r_{2-7}=\left(\begin{array}{rr}
59255 & -27539 \\
-27539 & 48115 \\
2998.9 & -26840 \\
-196.06 & 2969 \\
20.807 & -208.23 \\
35.292 & 70.042
\end{array}\right.
$$

Matriz rigidez de los rigidizadores 9,10 y12 de orden $6 \times 6$.

$$
r_{9-10-12}=\left(\begin{array}{rr}
89940 & -36139 \\
-36139 & 72881 \\
613.09 & -36748 \\
-186.09 & 502.83 \\
-2.4237 & -161.03 \\
53.924 & 63.825
\end{array}\right.
$$

Matriz rigidez de rigidizador 11 de orden $6 \times 6$.

$$
r_{11}=\left(\begin{array}{rr}
5852900 & -2850500 \\
-2850500 & 5509800 \\
106260 & -3113800 \\
-26504 & 313490 \\
101700 & -57573 \\
62099 & 124780
\end{array}\right.
$$

Matriz rigidez diagonal por rigidizadores verticales ( $r$ ) La matriz $r$ está conformada por los $\mathbf{r}_{\mathbf{i}}$ en la diagonal principal lo que equivale a que sea de orden $72 \times 72$.
Process in compliance with the analysis indicated.

Analysis A:

Determination of the following matrices for calculations:

a) Rigidity matrix for each stabilizer $\left(r_{i}\right)$

b) Diagonal rigidity matrix for vertical stabilizers $(r)$.

c) Matrix of influence $(A)$ and its transpose $\left(A_{t}\right)$.

d) Rigidity matrix for stabilizers (k).

e) Transposed connection matrix $\left(C^{t}\right)$ and $(C)$.

f) Structural system matrix rigidity $(\mathrm{K})$

g) Rigidity matrix of each stabilizer $\left(r_{i}\right)$

Rigidity matrix for wall shear stabilizers $\mathbf{1}$ and 8 in order $6 \times 6$.

Rigidity matrix of stabilizers $2,3,4,5,6$ and 7, order $6 \times 6$.

$\left.\begin{array}{rrrr}2998.9 & -196.06 & 20.807 & 35.292 \\ -26840 & 2969 & -208.23 & 70.042 \\ 48057 & -26836 & 2948.5 & -119.62 \\ -26836 & 48036 & -26762 & 2768.2 \\ 2948.5 & -26762 & 47234 & -23226 \\ -119.62 & 2768.2 & -23226 & 20445\end{array}\right)$

Rigidity matrix of stabilizers 9,10 and 12 , order $6 \times 6$.

$\left.\begin{array}{rrrr}613.09 & -186.09 & -2.4237 & 53.924 \\ -36748 & 502.83 & -161.03 & 63.825 \\ 72671 & -36696 & 486.05 & -93.165 \\ -36696 & 72642 & -36648 & 345.67 \\ 486.05 & -36648 & 71864 & -35558 \\ -93.165 & 345.67 & -35558 & 35167\end{array}\right)$

Rigidity matrix of stabilizer 11 , order $6 \times 6$.

$\left.\begin{array}{rrrr}106260 & -26504 & 101700 & 62099 \\ -3113800 & 313490 & -57573 & 124780 \\ 5645100 & -3069800 & 152500 & 158240 \\ -3069800 & 5494300 & -3161000 & 435560 \\ 152500 & -3161000 & 55453000 & -2581300 \\ 158240 & 435560 & -2581300 & 1774600\end{array}\right)$

Diagonal rigidity matrix by vertical stabilizer (r) The $r$ matrix is formed by the $r_{i}$ in the main diagonal which means that it is in the order $72 \times 72$. 
c) Matriz de incidencia (A) y su traspuesta $\left(A_{t}\right)$

La matriz de incidencia $(A)$ es una matriz de 1 y 0 , para relacionar los desplazamientos ordenados por rigidizadores $\left(y_{i}\right)$ con los desplazamientos ordenados por pisos $\left(z_{i}\right)$, por lo que también es de orden $72 \times 72$, y su traspuesta es obvio que tiene este mismo orden.

El ordenamiento de los desplazamientos verticales se realizó comenzando por el rigidizador 1 y así sucesivamente, al igual que en cada piso, comenzando por la primera planta.

\section{d) Matriz rigidez de rigidizadores (k)}

La matriz rigidez $k$ se obtiene pre $y$ post multiplicando la matriz $r$ por la matriz traspuesta de incidencia y la matriz sin trasponer respectivamente obteniéndose como es lógica, una matriz resultante de $72 \times 72$.

e) Matriz conexión traspuesta $\left(C^{t}\right)$ y $(C)$

La matriz conexión traspuesta está compuesta en su diagonal por las matrices conexiones traspuesta de cada piso, que en este caso, $C_{i}{ }_{i}$ son iguales, por tener la misma cantidad de rigidizadores en cada piso y en la misma posición.

Matriz rigidez $C^{t}{ }_{1}$ correspondiente al primer piso de orden $3 \times 12$.

c) Incidence Matrix (A) and its to transpose $\left(A_{t}\right)$ The incidence matrix $(A)$ is a matrix 1 and 0 , to relate displacement in function of stabilizers $\left(y_{i}\right)$ with displacements arranged by floors $\left(z_{i}\right)$, which is in the order $72 \times 72$, and its to transpose obviously has the same order.

The arrangement of vertical displacement begun with stabilizer 1 , at first floor from the first plan, the same at each floor.

\section{d) Stabilizer rigidity matrices (k)}

The rigidity matrix $k$, previous and post, is obtained multiplying the $r$ matrix by the incidence transposed matrix and the matrix without transpose respectively, resulting a matrix of $72 \times 72$.

\section{e) Transpose Matrix $\left(C^{t}\right)$ y $(C)$}

The transpose matrix is formed in its diagonal by the transposed connections of each floor, which in this case, $C_{i}{ }_{i}$ are equal due that each floor has different quantity and positions of stabilizers

The rigidity matrix $\mathrm{C}_{\mathrm{i}}{ }_{\mathrm{i}}$ corresponds to the first floor in order $3 \times 12$.

$$
C^{t}{ }_{1}=\left[\begin{array}{cccccccccccc}
0 & 0 & 0 & 0 & 0 & 0 & 0 & 0 & 1 & 1 & 1 & 1 \\
-1 & -1 & -1 & -1 & -1 & -1 & -1 & -1 & 0 & 0 & 0 & 0 \\
0 & 4.2 & 8.4 & 12.6 & 16.8 & 21 & 25.2 & 29.4 & 0 & 4.2 & 8.4 & 12.6
\end{array}\right]
$$

La matriz $\mathrm{C}^{\mathbf{t}}$ compuesta por las $\mathrm{C}_{\mathrm{i}}^{\mathrm{t}}$ en su diagonal es de orden $18 \times 72$ y $\mathrm{C}$ es de orden $72 \times 18$
The matrix $\mathrm{C}^{\mathrm{t}}$ formed by $\mathrm{C}_{\mathrm{i}}^{\mathrm{t}}$ in its diagonal, is of order $18 \times 72$ and $C$ is of order $72 \times 18$

f) The rigidity matrix of the structural system (K) Previous and post matrix $\mathrm{K}$ is obtained multiplying matrix $\mathbf{k}_{\mathbf{1}}$ by the transpose connection matrix and that connection without transpose, respectively as shown in; sin trasponer respectivamente como se muestra:

$$
K=C^{t}{ }_{(18 \times 72)} k_{1(72 \times 72)} C_{(72 \times 18)}=K_{(18 \times 18)}
$$

...que se corresponde con el orden de $3 n \times 3 n$.

...which corresponds to the order of $3 n \times 3 n$.

Matriz rigidez del sistema $\left(\mathrm{K}_{\mathbf{1 8} \times 18}\right)$

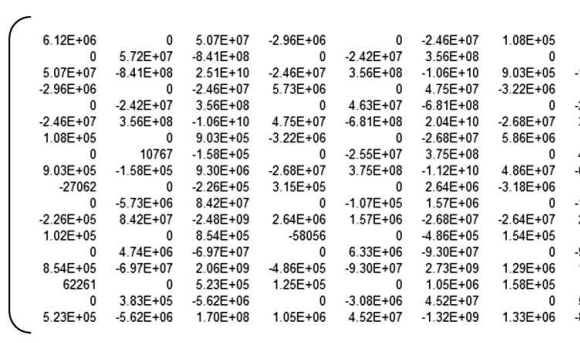

System rigidity matrix $\left(\mathrm{K}_{18 \times 18}\right)$

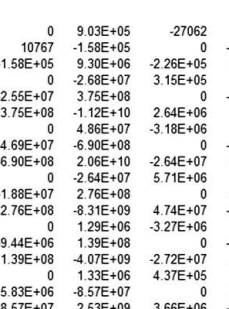

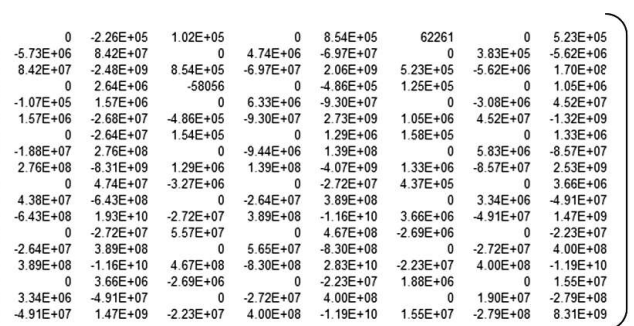


Con la obtención de esta matriz y el vector de los términos independientes $P$, se pueden obtener los desplazamientos por pisos aplicándose la Ecuación (1) a su vez con el vector $Z_{i(18 \times 18)}$, se obtienen los desplazamientos en cada rigidizador, $z_{i}(72 \times 72)$ y finalmente se obtienen las fuerzas en cada rigidizador, $p_{i(72 \times 72) \text {, estos }}$ resultados se muestran en las tabla resúmenes III, IV, V, VI y VII.

\section{Análisis B:}

a) Matriz rigidez de cada rigidizador $\left(r_{i}\right)$

Se modifica la matriz del rigidizador 11 por considerarse aporte espacial con efecto flexotorsor considerado, que ahora pasa a ser de orden $18 \times 18$.

Matriz rigidez del rigidizador 11
Obtaining this matrix and the vector of independent terms $P$, is possible to obtain displacement of floors using the equation (1), besides vector $Z_{i}(18 \times 18)$, allows obtaining displacements in each rigidity, $z_{i}$ (72x72) and finally the forces for each stabilizer, $p_{i(72 \times 72)}$, these results are shown in the summary tables III, IV, V, VI $y$ VII.

Analysis B:

a) Rigidity matrix for each stabilizer $\left(r_{i}\right)$

The matrix for stabilizer 11 are modified as considered an special contribution with the flexure torsion effect, which now has the order $18 \times 18$.

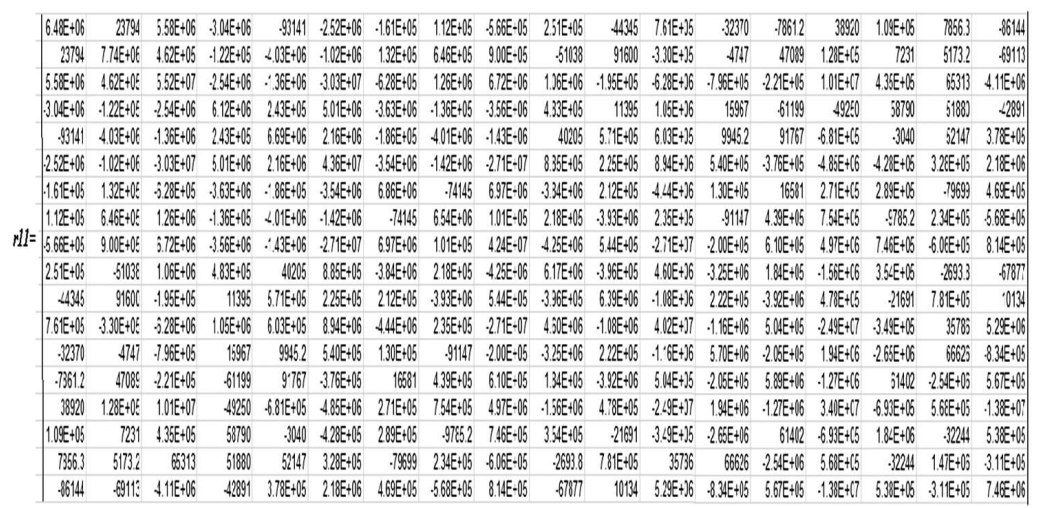

Los términos $r_{3 \mathrm{i} 3 \mathrm{j}}$ son modificados con la inclusión del efecto flexotorsor según Ecuación 8, realizándose el acople correspondiente para la determinación de todos los términos múltiplos de tres en los seis niveles de la estructura en que este rigidizador incide.

a) Matriz rigidez diagonal por rigidizadores verticales ( $r$ ) La matriz $r$ pasa a ser de orden $84 \times 84$, por adicionarse dos componentes de rigidez por piso.

b) Matriz de incidencia (A) y su traspuesta $\left(A_{t}\right)$

Ambas matrices también tienen el mismo orden que $r$ como en el caso anterior, el orden de $84 \times 84$.

c) Matriz rigidez de rigidizadores $(k)$

Esta matriz como es lógico también tiene el orden de $84 \times 84$.

d) Matriz conexión traspuesta (Ct) y (C)

Las matrices $C^{t}{ }_{i}$ pasan a ser de orden $3 \times 14$, de manera que la matriz $C^{t}$ tiene orden $18 \times 84$ y $C$ de $84 \times 18$.
The terms $\mathbf{r}_{3 \mathrm{i} 3 \mathrm{j}}$ are modified using the flexor torsion effect according the Equation 8, with the coupling to determine all the multiple terms in three of the six levels in which the stabilizer influence the structure.

a) Diagonal matrix rigidity by vertical stabilizers ( $r$ )

The matrix $r$ becomes order $84 \times 84$, because receives the rigidity components per floor.

b) The incidence matrix (A) and its transpose $\left(A_{t}\right)$

Both matrices have the same $r$ order as in the previous case, order de $84 \times 84$.

c) Rigidity matrix of stabilizers (k)

As logic this matrix has the order $84 \times 84$.

d) Transpose connection matrix (Ct) y (C)

Matrices $\mathrm{C}_{\mathrm{i}}{ }_{\mathrm{i}}$ take the order $3 \times 14$, in such way that matrix $C^{t}$ has the order $18 \times 84$ and $C$ 84x18. 
Matriz de rigidez $\mathrm{C}^{\mathrm{t}}{ }_{1}$ del primer piso

Rigidity matrix $C^{t}{ }_{1}$ of the first floor

$$
C^{t} 1=\left[\begin{array}{cccccccccccccc}
0 & 0 & 0 & 0 & 0 & 0 & 0 & 0 & 1 & 1 & 1 & 0 & 0 & 1 \\
-1 & -1 & -1 & -1 & -1 & -1 & -1 & -1 & 0 & 0 & 0 & 1 & 0 & 0 \\
0 & 4.2 & 8.4 & 12.6 & 16.8 & 21 & 25.2 & 29.4 & 0 & 4.2 & 8.4 & 29.4 & 1 & 12.6
\end{array}\right]
$$

e) Matriz rigidez del sistema estructural (K)

e) Structural system of the rigidity matrix (K)

$$
K=C_{(18 x 84)}^{t} k_{1(84 x 84)} C_{(84 x 18)}=K_{(18 \times 18)}
$$

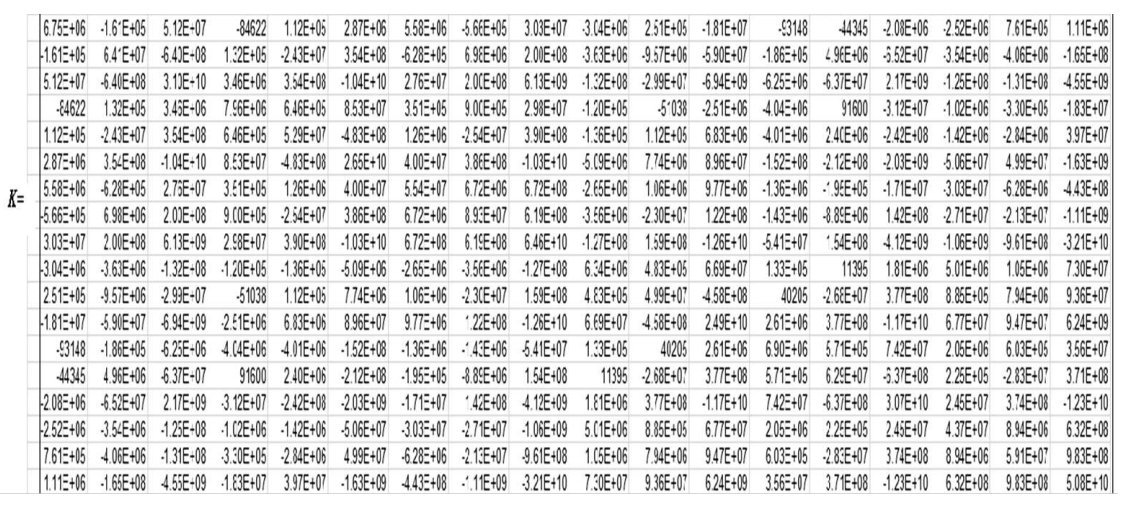

Como se observa el orden de la matriz del sistema no se altera, sin embargo difiere de la anterior en que los términos de rigidez varían su magnitud, pues se está considerando el aporte espacial de un rigidizador.

De igual manera que en el análisis $A$, se calculan los valores de desplazamientos por niveles $Z_{i}, z_{i}$ y $p_{i}$ y las magnitudes se resumen en las Tablas indicadas.

\section{Análisis C:}

Los resultados de la modelación en 3D realizada a través del STAAD.pro en términos de desplazamientos en cada nivel, se resume en la Tabla 3 .
As observed in the matrix system its order does not change, nevertheless it differs from the former with changes in the rigidity terms that change its size, because the spatial contribution of a stabilizer.

The same as in analysis $A$, there are calculations of displacements by levels $Z_{i}, z_{i}$ y $p_{i}$ and the sizes resumed in the indicated Tables.

Analysis C:

Table 3 resumes each displacement results per level of the 3D modeling done through.

Tabla 3. Desplazamientos por niveles $\left(Z_{i}\right)$ en cada tipo de análisis

\begin{tabular}{|c|c|c|c|c|c|c|c|c|c|}
\hline \multirow[b]{3}{*}{ Nivels } & \multicolumn{9}{|c|}{ Desplazamientos (m./Rad.) } \\
\hline & \multicolumn{3}{|c|}{ Análisis A } & \multicolumn{3}{|c|}{ Análisis B } & \multicolumn{3}{|c|}{ Análisis C } \\
\hline & $\mathrm{Zi}(\mathrm{x})$ & $\mathrm{Zi}(\mathrm{z})$ & Zi(ry) & $\mathrm{Zi}(\mathrm{x})$ & $\mathrm{Zi}(\mathrm{z})$ & Zi(ry) & $\mathrm{Zi}(\mathrm{x})$ & $\mathrm{Zi}(\mathrm{z})$ & $\mathrm{Zi}($ ry $)$ \\
\hline 1 & $-1.64 \mathrm{E}-11$ & $-2.55 \mathrm{E}-05$ & $1.94 \mathrm{E}-12$ & $-4.82 \mathrm{E}-06$ & $-1.64 \mathrm{E}-05$ & 4.64E-07 & 4.5E-07 & $-2.45 \mathrm{E}-05$ & $5.0 \mathrm{E}-08$ \\
\hline 2 & $-4.32 \mathrm{E}-11$ & $-6.22 \mathrm{E}-05$ & $5.11 \mathrm{E}-12$ & $-1.11 \mathrm{E}-05$ & $-3.89 E-05$ & 1.19E-06 & 8.7E-07 & $-6.1 \mathrm{E}-05$ & $9.0 \mathrm{E}-08$ \\
\hline 3 & $-7.68 \mathrm{E}-11$ & $-1.04 \mathrm{E}-04$ & $9.12 \mathrm{E}-12$ & $-1.82 \mathrm{E}-05$ & $-6.31 \mathrm{E}-05$ & 2.07E-06 & 1.27E-06 & $-1.01 \mathrm{E}-04$ & $1.3 \mathrm{E}-07$ \\
\hline 4 & $-1.05 \mathrm{E}-10$ & $-1.44 \mathrm{E}-04$ & $1.25 \mathrm{E}-11$ & $-2.61 \mathrm{E}-05$ & $-8.80 \mathrm{E}-05$ & $2.89 \mathrm{E}-06$ & 1.64E-06 & $-1.42 \mathrm{E}-04$ & $1.6 \mathrm{E}-07$ \\
\hline 5 & $-1.43 \mathrm{E}-10$ & $-1.83 \mathrm{E}-04$ & $1.71 \mathrm{E}-11$ & $-3.38 \mathrm{E}-05$ & $-1.11 \mathrm{E}-04$ & 3.69E-06 & 1.95E-06 & $-1.8 \mathrm{E}-04$ & $1.9 \mathrm{E}-07$ \\
\hline 6 & $-1.74 \mathrm{E}-10$ & $-2.19 \mathrm{E}-04$ & $2.08 \mathrm{E}-11$ & $-3.94 \mathrm{E}-05$ & $-1.32 E-04$ & 4.46E-06 & $2.2 \mathrm{E}-06$ & $-2.14 \mathrm{E}-04$ & 2.2E-07 \\
\hline
\end{tabular}

Table 3. Displacement per level $\left(Z_{i}\right)$ in each analysis.

\section{Notación:}

$Z_{i(x)}$ : Desplazamientos lineales en los distintos niveles en el sentido del eje $x$ global.
Notation:

$\mathrm{Z}_{\mathrm{i}(\mathrm{x})}$ : Linear displacement in different levels at the global orientation of axis. 
$Z_{i(z)}$ : Desplazamientos lineales en los distintos niveles en el sentido del eje $z$ global

$Z_{i(r y)}$ : Desplazamientos angulares en los distintos niveles en el sentido del eje y global

Observaciones: Los desplazamientos lineales por niveles $\left(Z_{i}\right)$ tienen signos negativos, esto significa que ocurren en la dirección positiva de los ejes de referencia en correspondencia con el convenio asumido para la fuerza actuante, pues la misma se considera negativa si está en la dirección positiva de dichos ejes como se muestra en el sistema base por pisos (Figura1), en el caso de los desplazamientos angulares el positivo significa que el giro es antihorario.
$\mathrm{Z}_{\mathrm{i}(\mathrm{z})}$ : Linear displacements in different levels at the global orientation of axis $z$

$Z_{i(r y)}$ :Angular displacements in different levels at the orientation of axis and global

Observations: The linear displacement per levels $\left(Z_{i}\right)$ has negative signs, this means that they occur in the reference axis positive direction in accordance with the acting force, this happens in the positive direction of the reference axis in accordance with the acting force, due that if it is in the positive direction of such axes is negative, as shown in the base system per floors (Figure1), in the case of angular displacement the turn is against the clock orientation.

Tabla 4. Desplazamientos lineales y angulares en los rigidizadores componentes. Análisis $\mathrm{A}$ Table 4. Angular and linear displacements in the stabilizer components. Analysis A

\begin{tabular}{|c|c|c|c|c|c|c|c|c|c|c|c|c|c|c|}
\hline \multicolumn{15}{|c|}{\begin{tabular}{l|l} 
Rrálisis & Análisss
\end{tabular}} \\
\hline Rigid. & 1 & 2 & 3 & 4 & 5 & 6 & $?$ & 8 & 9 & 10 & & & 11 & 12 \\
\hline Desples. & 4 & 4 & 3 & 4 & 8 & 2 & 7 & 48 & 29 & 2,10 & 4.11 & 7.1.1. & 2.1" & 4 \\
\hline Wroles & & & & & & & & & & & & & & \\
\hline & 25SEDS & 25SENS & 255E.0.5 & 2.5S50.05 & 2558.05 & 25S5E. 05 & 25580.05 & 2255E.05 & $.1648: .11$ & 8.868 .12 & .138 .13 & 0 & 0 & 80008.12 \\
\hline & 6228005 & 6.228.-15 & 6.220 .05 & 6.228.05 & 6.228.05 & 6028.05 & 6.228.05 & 6.228.05 & -4328.11 & 2.178.11 & .25 .13 & \begin{tabular}{l|l}
3 & 0
\end{tabular} & 0 & 2.128 .11 \\
\hline & 1.04:-04 & 1.048 .04 & 1.048 .04 & 10480.04 & 1.04E.NA & 1.04:.N4 & $\overline{1.04604}$ & 1.048:14 & $.7688 \mathrm{E} \cdot 11$ & 3.885 .11 & .24 .13 & 0 & 0 & $381[.11$ \\
\hline & 1.4ENA & 1 . AERA4 & 1.4E:DA & 1.44604 & $1.46 \cdot \sqrt{1}$ & $1.4 E \mathbb{N A}$ & 1.480 .4 & $1.4 E N A 4$ & $.1058-10$ & .5266 .11 & .236 .13 & 0 & 0 & 5.22811 \\
\hline & 1.848004 & 1.84604 & 18480.04 & 1.84004 & 1848.04 & 1.846 .04 & 1886014 & 1.84604 & .1 .938 .10 & .81780 .11 & $2660+14$ & 40 & 0 & 1.12811 \\
\hline & 21.980 .04 & 2.198 .04 & $2198: 04$ & 2.19804 & 2.198 .04 & 2.198 .04 & 219804 & 21.98 .04 & .1 .348 .10 & $8.87 \mathrm{E}: 11$ & 2008.13 & 30 & 0 & 88.E: 11 \\
\hline
\end{tabular}

Gráfico 1. Desplazamientos por cada rigidizador en los distintos niveles en correspondencia con el análisis A

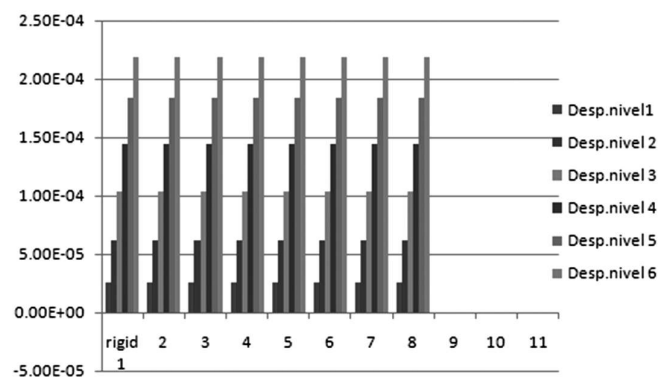

Tabla 5. Desplazamientos lineales y angulares en los rigidizadores componentes .Análisis B

Table 5. Angular and linear displacements in the components of stabilizers .Analysis B

\begin{tabular}{|c|c|c|c|c|c|c|c|c|c|c|c|c|c|c|}
\hline \multicolumn{15}{|c|}{ Wriliss knalicis } \\
\hline Pyod & $T$ & ! & 3 & 4 & s & 6 & 1 & 8 & & 10 & & & III & 12 \\
\hline Deqfor & 4 & 8 & 9 & 4 & 8 & 2 & $n$ & 8 & 8 & in & 4) & 4 & 811" & 4 \\
\hline resel & lofeNs & 138000 & 20000 & 202010 & 24005 & $26 \mid \mathbb{E D S}$ & 281EC" & 30005 & .48286 & 1.28026 & .210N & 1.23260 & $46 \mathrm{SON}$ & IWECW \\
\hline & 390005 & $4380 \mathrm{ST}$ & 4900000 & 93900 & $\sec 005$ & 639005 & 609005 & $13300 \mathrm{CO}$ & IIIENS & .005006 & || $\mathbb{E D N} \mid$ & 38806 & 1.190006 & 395206 \\
\hline & G3EOS & 118000 & SOCOENG & 89800 & QNECS & LOECNA & LISEOA & 12004 & 1.20205 & .952000 & 800 & 2006 & 1200206 & 180006 \\
\hline & $\triangle O D O C$ & LONRA & 1.120204 & $1.28 \mathrm{WO}$ & BSECA & 1.96N & 16GQW & 13500 & . 260105 & - IACOSS & .19000 & 32026 & 1289000 & 102015 \\
\hline & $1 \| \mathbb{E} \mathbb{4}$ & $120 N A 4$ & 1980N & 1.5800 & I.3ECA & 198CN & 2NECA & $2 E N A$ & 332015 & .13005 & .28060 & 1.2806 & 300000 & IIRENS \\
\hline & $13 E N A$ & ISECQ & 10004 & 18000 & WNCA & 20EN & 24004 & 260004 & 3aces & .2000005 & .19060 & & 4602010 & 1002015 \\
\hline
\end{tabular}


Gráfico 2. Desplazamientos por cada rigidizador en los distintos niveles en correspondencia con el análisis B

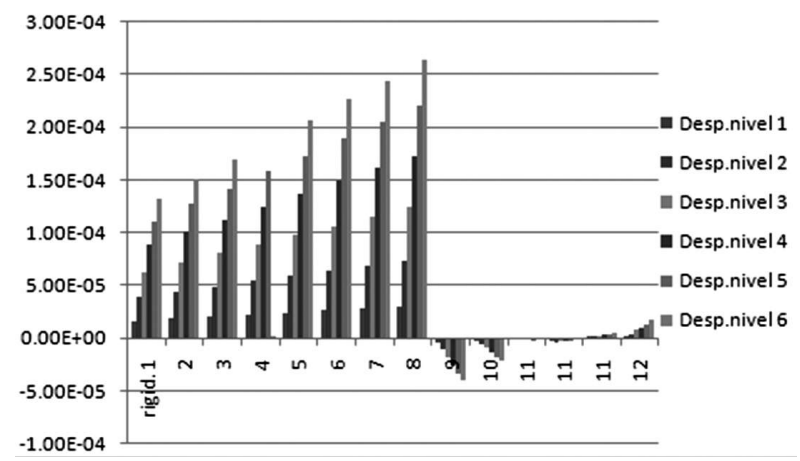

Tabla 6. Fuerzas que se distribuye a cada rigidizador del sistema. Análisis A Table 6. Forces distributed in each stabilizer of the system. Analysis A

\begin{tabular}{|c|c|c|c|c|c|c|c|c|c|c|c|c|c|c|}
\hline \multicolumn{15}{|c|}{\begin{tabular}{|l|l|} 
Shaliss & Analisis h \\
\end{tabular}} \\
\hline Rigid & $!$ & 1 & 3 & 4 & s & 6 & 1 & & & 10 & & & III & 12 \\
\hline Furass. & D & 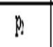 & $p$ & $P$ & $p_{s}$ & $p_{i}$ & $p$ & ps & $p$ & pin & PII & 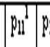 & pu" & PII \\
\hline & 3986Ct]. & 0,0914 & 9.4602 & 9.1602 & 9.4602 & 9,4002 & 00091821 & 398911 & SOEDED & $235 \mathrm{ED}$ & 440080 & & 0.2 & Cosene \\
\hline & 46349 & 0.080 & .00829 & .0000 & .0 .000 & .00809 & .0080 & 4.34 & 236000 & 1.11E:? & .228010 & & 0.1 & \\
\hline & \$21. & 0028 & 0.028 & 0.028 & 0,028 & 0.028 & 0.028 & $\$ 22060$ & 2068007 & 1038.07 & 20070.010 & & $\begin{array}{lll}0 & 11 \\
\end{array}$ & 1038.07 \\
\hline & 33.45 & 0.035 & 0.035 & 0.035 & 0.035 & 0.035 & 0.0.S & 33.45 & 368.0. & 1800:D & .3560010 & & \begin{tabular}{l|l}
0 & 1 \\
\end{tabular} & 1968.07 \\
\hline & 596011 & 0.0045 & 0.0045 & 00045 & 0.045 & 0.0045 & 0.004 & 59.612 & .29480 .07 & $.15 Q D$ & \begin{tabular}{ll|l}
3340.010 \\
\end{tabular} & & 01 & 128.07 \\
\hline & 20.035 & 0.612 & 0.612 & 0.612 & 0.612 & 0.612 & 0.612 & 20.03 & .1060 .06 & .51720 .07 & 10018.060 & & 05 & 3650.07 \\
\hline
\end{tabular}

Observaciones: Los signos de las fuerzas se interpretan de acuerdo al convenio asumido en el método PPG modificado y las unidades vienen dadas en el SIU, es decir las fuerzas se expresan en $\mathrm{kN}$ y los momentos de fuerzas en $\mathrm{kN}-\mathrm{m}$.
Observations: The signs in forces are interpreted according to what was agreed in the modified method PPG and the units are given by SIU, that is to say forces are expressed in $\mathrm{kN}$ and the moment of forces in $\mathrm{kN}-\mathrm{m}$.

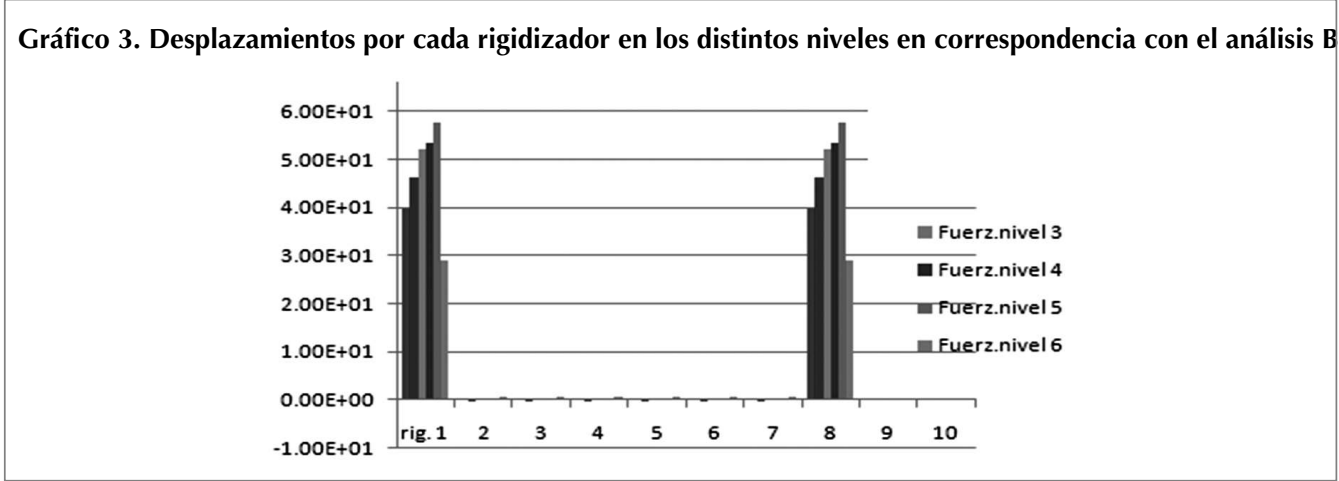

\begin{tabular}{|c|c|c|c|c|c|c|c|c|c|c|c|c|c|c|}
\hline \multicolumn{15}{|c|}{\begin{tabular}{l|l|} 
Andilisis & Andidisis \\
\end{tabular}} \\
\hline Bigid & 1 & 2 & 3 & 4 & S & 6 & 1 & 8 & 8 & 10 & & & 11 & \\
\hline Furass. & n & $p$ & $m$ & 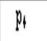 & $p$ & $p$ & $p$ & $p_{s}$ & pq & Pln & Pl1 & $p_{n}{ }^{n} p^{p}$ & & PII \\
\hline thels ! & 35.57 & 0.0815 & 0.0839 & 0.0800 & 0.0883 & 00096 & 0.0020 & 4.835 & 5.0024 & 4.0 .041 & 0.1336 & 6.223 & 606 & .004 \\
\hline & 4.96 & .00398 & .00516 & 0.0635 & .00733 & 0.0882 & .0099 & 48,19 & 0.00233 & 0.003 & .00019 & 19.2 .3 & 503 & .0032 \\
\hline 3 & 1936 & .00029 & 00039 & 000109 & 00019 & 0.0248 & 0.0338 & 69262 & 000615 & 0.0333 & 0.01153 & 33.1716 & 12,43 & 0.058 \\
\hline 4 & 33.11 & 0.032 & 0.0334 & 0.033 & 0.034 & 0.034 & 0.0355 & 63221 & .0008 & .00075 & 0.0203 & 8.988 & 1.88 & .0000 \\
\hline & 47.15 & 0.0137 & 000112 & 0.008 & 0.0062 & 0.036 & 0.0011 & 02228 & .0075 & \begin{tabular}{|l|l|}
5.0001 \\
\end{tabular} & 0.031. & 41.493. & .0248 & .00534 \\
\hline & 8085 & 0.4075 & 0.434 & 05199 & 0.9322 & 0.6311 & 0.6800 & 39.02 & \begin{tabular}{|l|l|l|l|}
2.1917 \\
\end{tabular} & $\begin{array}{ll}19.0 .0003 \\
\end{array}$ & $\begin{array}{l}330.205 \\
\end{array}$ & 10.3. & .0901 & 0.14 \\
\hline
\end{tabular}

Tabla 7. Fuerzas que se distribuye a cada rigidizador del sistema. Análisis B Table 7. Forces distributed in stabilizer of the system. Analysis B 
Nereyda Pupo Sintras, Carlos A. Recarey Morfa

Gráfico 4. Fuerzas que se distribuyen en cada uno de los rigdizadores en correspondencia con el análisis B

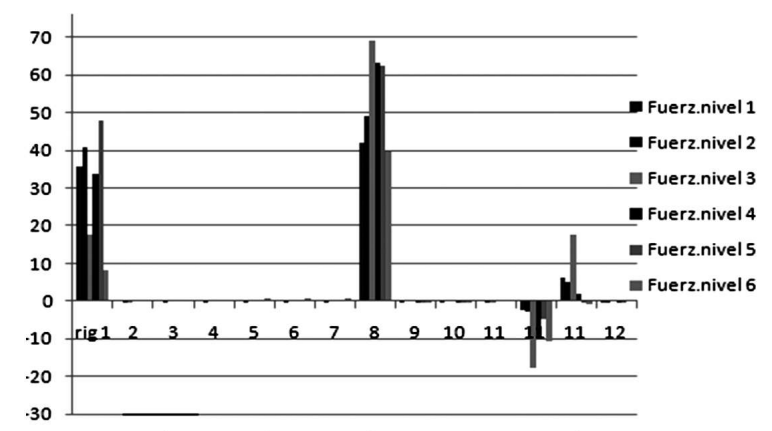

Gráfico 5. Desplazamientos lineales y anulares (Zi) en los distintos niveles y en correspondencia con los tres análisis efectudos

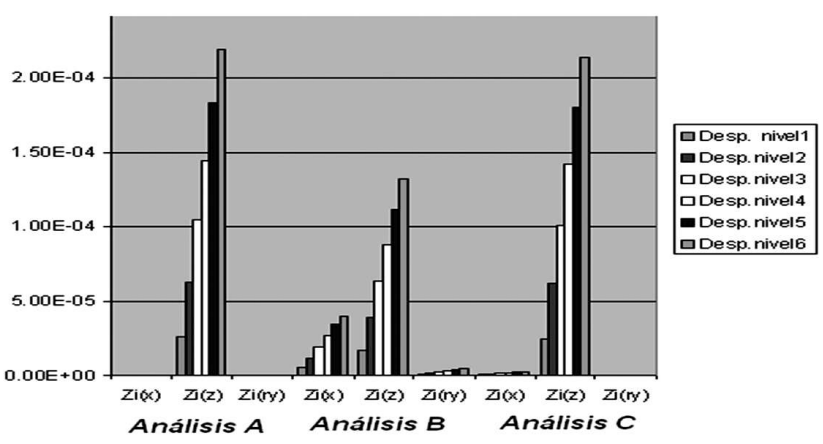

Gráfico 6. Curvas de variaciones de las deformadas de rigidizadores. Modelo A

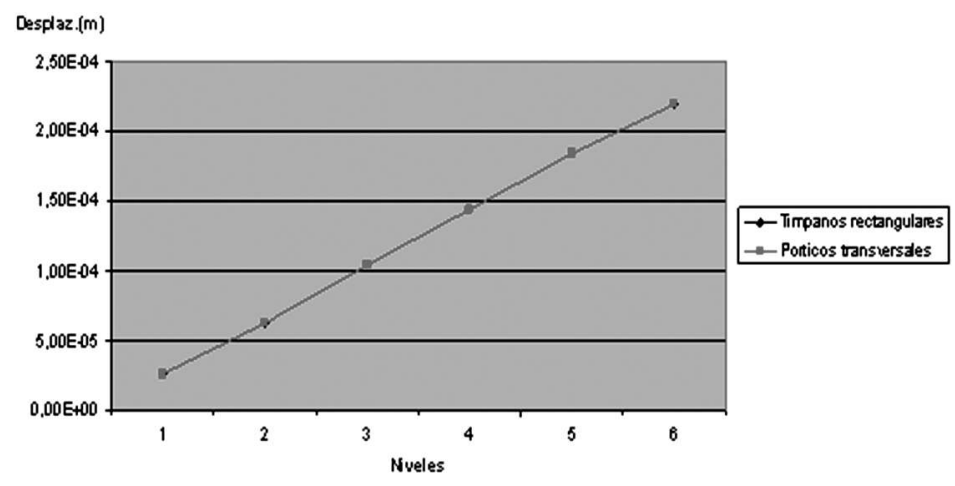

Gráfico 7. Curvas de variaciones de las deformadas de rigidizadores. Modelo B

Diplaz (m)

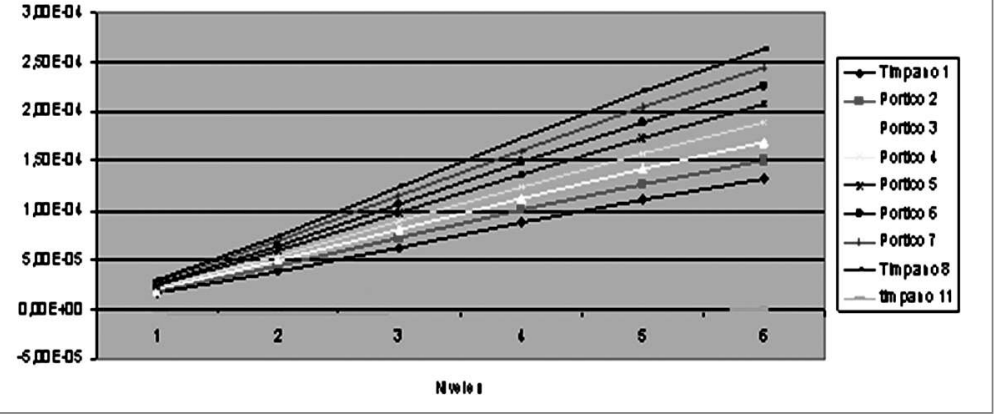


Gráfico 8. Curvas de variaciones de las deformadas de rigidizadores. Modelo C

Desplaz. (m)

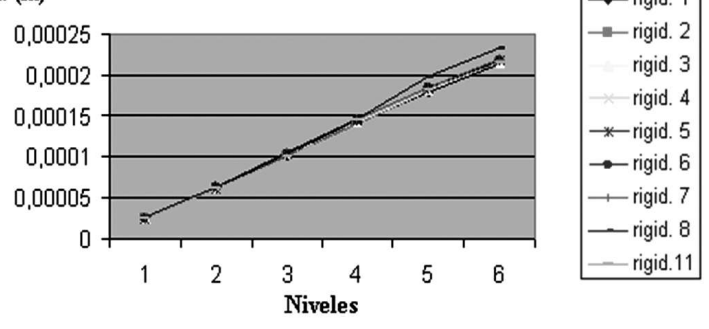

Gráfico 9. Variación de los desplazamietos de rigidizadores. Análisis C

Despha (m)

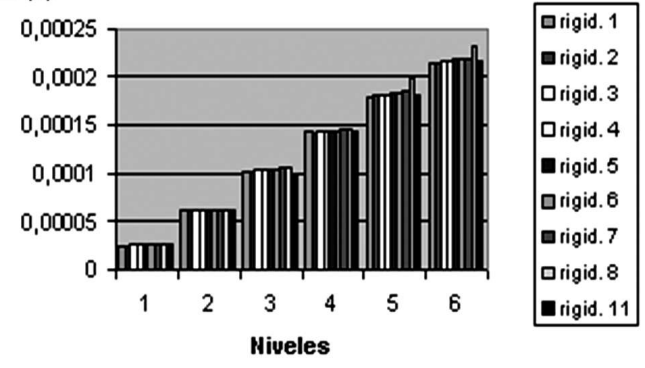

Tabla 8. Desplazamientos en rigidizadores. Análisis C

Table 8. Displacement in stabilizers. Analysis C

\begin{tabular}{|c|c|c|c|c|c|c|c|c|c|c|c|c|c|c|}
\hline Arilitis & andiescic & & & & & & & & & & & & & \\
\hline Big & & & & & & & & & & 1 & II & $\|^{1}$ & $\|^{\mathbb{T}}$ & \\
\hline 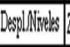 & 4 & 4 & G & 4 & 3 & 4 & 4 & th & द. & Zin & $z_{11}$ & & $24]^{2}$ & \\
\hline & $0,0,0020240$ & 0,00020 & $0,0,0003$ & 2000020 & $0,0,000035$ & $0,0,00025$ & 0,000029 & 0,000020 & & & & $0,0,000325$ & & \\
\hline & 0,0003011. & $0,0,003515$ & $0,0,0006019$ & 0000002 & $0,0,00000$ & $0,0,00000$ & $0,0,00334$ & $0,0,00303$ & & & & 0,0000202 & 0 & \\
\hline & 0,000100 & 0,0001010 & 0,000103 & 000000 & 0,00004 & 0,00004 & 0,000100 & $0,0,00015$ & & & & a,0,00: & 0 & \\
\hline & $0,0,0014$ & $0,0,0044$ & 0,00018 & 0,000142 & $0,000,40$ & $0,0,0046$ & 0,00074 & $0,0,001919$ & & & & $0,0,0144$ & & \\
\hline & $0,0,01010$ & 0,001818 & 0,00018 & 0000180 & 0,000080 & 0,0000828 & 0,000188 & $0,0,000$ & & & & 0,000180 & & \\
\hline 6 & 0,002024 & $0,0,0215$ & 0,002020 & 20002017 & 0,00028 & 0,000218 & 0,000219 & $0,0,0023$ & & & & $0,0,0216$ & & \\
\hline
\end{tabular}

Tabla 9. Porcentaje (\%) de absorción de las cargas laterales por parte de los rigidizadores (pórticos y tímpanos) en correspondencia con el Análisis A

Table 9. Percentage (\%) of lateral load absorption by the stabilizers (frame and shear walls) in accordance to analysis $\mathrm{A}$

\begin{tabular}{|c|c|c|c|c|c|c|}
\hline & niveles & & & & & \\
\hline Rigidizador & 1 & 2 & 3 & $\begin{array}{c}4 \\
\end{array}$ & 5 & 6 \\
\hline timpano1 & 44,36 & 44,43 & 16,8 & 31,5 & 41,41 & 13,09 \\
\hline pórtico 2 & 0,11 & $-0,04$ & 0 & 0 & 0 & 0,6 \\
\hline pórtico 3 & 0,105 & 0 & 0 & 믄 & 0 & 0,75 \\
\hline pórtico 4 & 0,107 & $\overline{0}$ & 0 & 0 & 0 & 0,84 \\
\hline pórtico 5 & 0,109 & 0 & 0 & 0 & 0 & 0,93 \\
\hline pórtico 6 & 0,11 & 0 & 0 & $\overline{0}$ & $\overline{0}$ & 1,02 \\
\hline pórtico 7 & 0,116 & $-0,1$ & 0 & 0 & 0 & 1,11 \\
\hline tímpano 8 & 52,18 & 53,06 & 66,28 & 61,88 & 54,23 & 64,3 \\
\hline pórtico 9 & 0 & 0 & 0 & 0 & 0 & 0 \\
\hline pórtica 10 & 0 & 0 & 0 & 0 & 0 & 0 \\
\hline tímpano 11 & $\overline{0}$ & $\overline{0}$ & 0 & 0 & 0 & 0 \\
\hline tímpano 11 & 2,78 & 2,96 & 16,84 & 9,23 & 4,28 & 17,33 \\
\hline tímpano 11 & 0 & 0 & 0 & 0 & 0 & 0 \\
\hline pórtico 12 & 0 & 0 & 0 & 0 & 0 & 0 \\
\hline
\end{tabular}


Tabla 10. Porcentaje (\%) de absorción de las cargas laterales por parte de rigidizadores (pórticos y tímpanos) en correspondencia con el modelo B

Table 10. Absorption percentage (\%) of lateral loads by stabilizers (frames and shear walls) in accordance with model B

\begin{tabular}{|r|r|r|r|r|r|r|}
\hline & niveles & \multicolumn{6}{|c|}{} \\
\hline Rigidizador & 1 & 2 & 3 & 4 & 5 & 6 \\
\hline timpano1 & 44,36 & 44,43 & 16,8 & 31,5 & 41,41 & 13,09 \\
\hline pórtico 2 & 0,11 & $-0,04$ & 0 & 0 & 0 & 0,6 \\
\hline pórtico 3 & 0,105 & 0 & 0 & 0 & 0 & 0,75 \\
\hline pórtic0 4 & 0,107 & 0 & 0 & 0 & 0 & 0,84 \\
\hline pórtic0 5 & 0,109 & 0 & 0 & 0 & 0 & 0,93 \\
\hline pórtico 6 & 0,11 & 0 & 0 & 0 & 0 & 1,02 \\
\hline pórtico 7 & 0,116 & $-0,1$ & 0 & 0 & 0 & 1,11 \\
\hline tímpano 8 & 52,18 & 53,06 & 66,28 & 61,88 & 54,23 & 64,3 \\
\hline pórtico 9 & 0 & 0 & 0 & 0 & 0 & 0 \\
\hline pórtico 10 & 0 & 0 & 0 & 0 & 0 & 0 \\
\hline tímpano 11 & 0 & 0 & 0 & 0 & 0 & 0 \\
\hline tímpano 11 & 2,78 & 2,96 & 16,84 & 9,23 & 4,28 & 17,33 \\
\hline tímpano 11 & 0 & 0 & 0 & 0 & 0 & 0 \\
\hline pórtico 12 & 0 & 0 & 0 & 0 & 0 & 0 \\
\hline
\end{tabular}

\section{Evaluación de los resultados}

Referido al trabajo conjunto de pórticos y tímpanos, en este caso, un edificio de 6 niveles (pocos pisos), convenientemente rigidizado por tímpanos de sección rectangular cuya relación altura a longitud de los mismos es relativamente pequeña $(h / l<2)$, no se presenta la interacción compleja que sucede cuando el edificio tiene varios niveles, por lo que en este edificio los tímpanos son los que absorben el mayor porcentaje de las cargas laterales desde el piso 1 hasta el piso 6, debido a que presentan mayor rigidez que los pórticos en toda la altura del edificio.

En el Análisis A, tanto los pórticos como los tímpanos se desplazan igual, describiéndose la misma deformada según se muestra en el Gráfico 6 y los valores de desplazamientos se observan en la Tabla 4. Este comportamiento se origina debido a que no se considera el efecto de rigidez ortogonal (en dirección de la carga) del tímpano canal, lo que hace que la estructura sea simétrica y se verifique una traslación uniforme en todos los pisos.

El mayor porcentaje de la absorción de las cargas es tomado por los tímpanos desde el nivel 1 hasta el nivel 6, como se muestra en la Tabla 9.

En el Análisis B, los pórticos y los tímpanos, en este caso, se desplazan de manera diferente, según se muestra en el Gráfico 7 y los valores de desplazamiento se observan en la Tabla 5. Este comportamiento a diferencia del modelo anterior se fundamenta en el hecho en que se esta considerando aporte espacial con efecto flexotorsor del rigidizador canal. Este modelo, más cercano a la realidad, establece la asimetría de la planta y la no coincidencia del centro de cortante con el centro de gravedad generándose la torsión, se verifica por lo tanto una redistribución de las cargas laterales que aunque el mayor porciento sigue siendo tomado por los tímpanos rectangulares,

\section{Assesment of results}

In relation to the common work of frames and shear walls - in this case a six level building (few floors) - conveniently stabilized by shear walls of rectangular section, which height length relation is small $(h / l<2)$, lacks of the complex interaction that appears when the building has several floors, because in that buildings the shear walls are what absorbs the longer percentage of lateral loads from floor 1 until 6, because it present more rigidity than frames all along the heath of building.

The frames, in the analysis A, as shear walls, displace equally, with the same deformation as shown in Graphic 6 and the displacement values are observed in Table 4. This behavior is because the orthogonal rigidity (at load direction) of the shear wall is not considered which makes the structure symmetric and verifies a uniform transition in all the floors.

The longer percentage of load absorption comes from the shear walls from level 1 to 6 , as shown in Table 9.

Frames and shear walls, in analysis B displace differently, according to the information at Graphic 7 and displacement levels are observed in Table 5. This behavior, in opposition of the former model, is based in the fact of considering the spatial effect contribution with the flexor torsion effect of channel stabilizer. This model, closer to reality, sets asymmetry to the plan and no coincidence of the shear center with the gravity center, producing torsion, then there is a verification of lateral loads, which besides the bigger percentage, are still considered rectangular shear walls, 
es significativo notar que el tímpano canal también llega a absorber hasta un $17 \%$ de esta carga en el nivel 3 . El porcentaje de la absorción de las cargas laterales por parte de los pórticos es despreciable en relación a los tímpanos mencionados debido a su menor rigidez, esto se verifica desde el nivel 1 hasta el nivel 6 como se presenta en la Tabla 10.

En el Análisis C, los pórticos y los tímpanos se desplazan de forma similar $y$ semejante al comportamiento que ocurre en el modelo $A$, esto se fundamenta en el hecho de que aunque en la modelación del edificio se considera aporte espacial de todos los rigidizadores, la rigidez a la torsión es despreciable tanto en los pórticos como en tímpanos de sección rectangular y de sección abierta (canal) como se muestra en los Gráficos 8 y 9 y la magnitud de los desplazamientos aparece en la Tabla 8. Al mismo tiempo, el efecto flexotorsor no se considera, esto hace que este comportamiento difiera del modelo $B$, en el cual si se considera este efecto durante el proceso de modelación del sistema estructural.

El empleo del método de los elementos finitos en este caso garantiza resultados exactos por una parte, por tratarse de geometrías regulares y comportamiento elástico y lineal, pero no contempla automáticamente el análisis del efecto flexotorsor en los tímpanos de sección abierta, dado que no está implícito en el proceso de fundamentación teorica del software especializado empleado, por otro lado, el volumen de resultados es numeroso, se obtienen tensiones y desplazamientos por nodos de los elementos finitos que componen la geometría de los tímpanos analizados, pero no se conoce de forma explicita la fuerza que recibe cada rigidizador, ni las solicitaciones de momento flector y cortante en los tímpanos, lo que resulta una desventaja de este análisis.

Como tendencia los desplazamientos que se generan del análisis espacial $B$ resultan ser menores en magnitud que los obtenidos del análisis A y del análisis $C$, esto se fundamenta por considerarse en el análisis B mayor rigidez, con la introducción del efecto flexotorsor en el tímpano de sección canal, según se muestra en el Gráfico 5.

Estos resultados fundamentan la importancia que tiene la tipología y posición en planta de rigidizadores de paredes delgadas y de sección abierta en relación al resto de los rigidizadores, de manera que se garantice reducciones significativas del ángulo de torsión y distribución racional de las fuerzas actuantes entre los rigidizadores que participan como estructuras verticales resistentes. it is important to note that the channel shear wall absorbs until a $17 \%$ of the lateral load at level 3 .

The absorption percentage of lateral loads, by frames is less significant in relation to the shear walls mentioned, due to its minor rigidity, this is verified from level 1 up to level 6, as shown in Table 10 .

At $C$, frames and shear walls moves in similar way to the behavior at model $A$, this is because besides that the building modeling is considered spatial contribution of all the stabilizers, torsion rigidity is insignificant as in frames or shear walls of rectangular and opened sections (channel) as shown in Graphics 8 y 9 y and the magnitude of displacements as shown in Table 8. The effect flexure torsion, at the same time, is not considered, this makes that behavior differs to model $B$, which considers this effect during the system structural modeling.

The method of the finite elements, in this case guarantees, exact results by one side due to regular geometries and elastic linear behaviors, but it does not automatically considers the flexor torsion analysis in shear walls of opened sections, because this is not implicit in the software theoretical foundations, by other side the volume of results is big, tensions and displacement are obtained per nodes of the finite elements, which form the geometry of the shear walls in analysis; but the force that each stabilizer receives is unknown, the same as loads in the flexor and shear moment at shear walls, that represents a disadvantage of this analysis.

The tendency of displacements in the spatial analysis $B$ are less in magnitude than those obtained with analysis $A$ and $C$, the base of this is because analysis $B$ has more rigidity, adding the flexor torsion effect at the shear wall of channel section, as shown in the Graphic 5.

These results fundament that type and position in the plan of wall stabilizers and opened section is relevant in relation to the rest of stabilizers, for a granted reduction of the torsion angle and a rational distribution of acting forces among the stabilizers that act as resistant vertical structures. 


\section{Conclusiones}

Se constata la influencia que tiene en el comportamiento espacial de un sistema estructural, la presencia de un rigidizador de pared delgada y de sección abierta, pues se produce una disminución significativa en la magnitud de los desplazamientos, así como, se manifiesta la distribución de la carga externa de forma racional entre los rigidizadores que participan en el sistema.

El método PPG modificado cubre un amplio espectro de soluciones estructurales de rigidización vertical, como son tímpanos y pórticos combinados (o aún la combinación de ambos en un mismo rigidizador), no paralelismo de estos elementos en todos los pisos y niveles de cimentación a distinta altura.

También pueden aparecer tímpanos con huecos, tímpanos con rigidez a la torsión apreciable y tímpanos en que las tensiones producidas por el bimomento y el momento flexotorsor son considerables.

Este último aspecto tratado en detalle en este trabajo le concede al método generalidad incomparablemente mayor en relación a su formulación inicial y también resulta ventajoso comparado con los software especializados que no reflejan este comportamiento.

La hipótesis considerada es la de entrepiso rígido, sin embargo los autores de este artículo trabajan en la formulación para entrepisos flexibles en su propio plano.

\section{Conclusions}

The relevance of a structural system over a spatial behavior is shown, that is to say the presence of a thin wall and opened section stabilizer, because there is a relevant reduction in the displacements magnitude, as expressed in the rational external load distribution among stabilizers that participate in the system.

The modified PPG method covers wide spectra of the vertical rigidization structural solutions, as a combination of shear walls and frames (or even the combination of both in a same stabilizer); no parallelism of these elements in all the floors with different foundation levels at different height.

Shear walls with hollows may appear too, shear wall with notable torsion rigidity and shear walls with a considerable torsion rigidity produced by bimoment and the flexo torsion moment.

This last point detailed in this paper, recognizes the method an incomparable generality in relation to its initial formulation, and also results an advantage in comparison with specialized softwares which do not reflect this behavior.

The considered hypothesis is the one of rigid space between floors, but this article authors work in formulating something for flexible spaces between floors in its own plan.

\section{Referencias / References}

Bonilla O. (2003), "Análisis de la influencia del alabeo en estructuras ensambladas con elementos de pared delgada." -TG; Escuela Superior de Ingeniería y Arquitectura, Instituto Politécnico Nacional, México.

Brizuela Y. (2004), "Análisis de la distribución de fuerzas horizontales en los sistemas mixtos empleados en los edificios altos II"; MSc Ing. Nereyda Pupo Sintras, tutor. -TD; UC. (Const). 133 pág.

Fujitani Y y Fujii D. (1998), "A structural analysis method of framed structures with thin-walled open section members based on the bending-torsional theory of beams." Computational Mechanics. CIMNE, Barcelona, Spain. 1998.

Gonzáles J. (1985), "Aplicación del método de la matriz transferencia al análisis de tímpanos con hueco." Revista de Ingeniería Estructural y Vial.

González J. (2004), "Fenómeno de la flexo-torsión en elementos considerados perfiles abiertos de paredes delgadas." Trabajo para I Congreso de Ingeniería estructural. Stgo. de Cuba.

Gutiérrez P. (1964), "Flexión y torsión de perfiles de paredes delgadas de sección abierta" Revista Ciencias Técnicas. Serie Ingeniería Civil, No.1. Hernández J. (1967), "Fuerzas laterales en edificios con tímpanos." Revista de Ingeniería Civil (Habana) (12).1967.

Hernández J. (1994), "Métodos de distribución de fuerzas horizontales en edificios con pórticos y tímpanos." Revista Ciencias Técnicas. Ingeniería estructural y vial, Vol. XV, No. 2.

Hernández, et al. (1994), "Distribución de fuerzas laterales en edificios de hormigón armado." Revista Ciencias Técnicas. Ingeniería estructural y vial, Vol. XV, No. 2.

Lin T. (1964), "Distribución de fuerza lateral en un edificio de hormigón." Revista Ingeniería Civil.

NC-205-2003, "Cargas de viento: Métodos de cálculo."

Pupo N. (2001), "Análisis de edificios altos. Método de distribución de fuerzas horizontales." Dr. Carlos A. Recarey Morfa, tutor. -TM; UC. (Const). 76 pág. Recarey C., Pupo N. (2003), "Análisis de estructuras edificios altos." Revista de Ingeniería No. 17. Universidad de Los andes. Colombia. 2003. Recarey C., Pupo N. (2003), "Método de distribución de fuerzas laterales en edificios."Revista Ingeniería civil. Barcelona. CEDEX No. $132 / 2003$.

Recarey C., Pupo N. (2004), "Formulación de un método de distribución de fuerzas horizontales en edificios altos." Revista internacional de métodos numéricos para cálculo y diseño en ingeniería. Vol. XX, 1, pág 61-76 2004.

Ruiz S. (1975), "Efecto del momento flexo-torsor en los diafragmas de Sección I." Revista Ciencias Técnicas. Serie Ingeniería Civil, No 6, $511-533$.

Ruiz S., Gonzáles J. (1979), "Influencia de de la fuerza cortante en la carga horizontal tomada por cada tímpano de un sistema cualquiera." Revista de Ciencias técnicas. Ingeniería estructural. 1979.

Ruiz S., Bonilla O. (1996), “Coeficientes de rigidez para vigas de pared delgada.” X Congreso Nacional de Ingeniería Estructural, Mérida, Yucatán, México. Ruiz S, Bonilla O. (2006), "An stiffness coefficients proposal for thin walled open beams." Revista Técnica Ingeniería Universidad de Zulia Vol. 29 No. 3 Maracaibo.

Tejera P. (1992), "Análisis de edificios esbeltos con distribución general de los rigidizadores en planta, sometidos a la acción de cargas laterales." -TD. Ciencias Técnicas.

Vallecilla C. (2005), "La torsión en las construcciones." Ediciones Unisalle.

Vlazov V. (1961), "Thin Wallet Elastic Beams." National Technical Information Service, U.S. Department of Commerce. 1961. 